Original article

\title{
Synthesis and preliminary mechanistic evaluation of 5-( $p$-tolyl)-1- (quinolin-2-yl)pyrazole-3-carboxylic acid amides with potent antiproliferative activity on human cancer cell lines
}

\author{
Şeyma Cankara Pirol a, Burcu Çalışkan ${ }^{\text {a }}$, İrem Durmaz ${ }^{\text {b }}$, Rengül Atalay ${ }^{\text {b, c }}$, \\ Erden Banoglu a, * \\ a Department of Pharmaceutical Chemistry, Faculty of Pharmacy, Gazi University, Etiler, 06330 Ankara, Turkey \\ ${ }^{\mathrm{b}}$ Department of Molecular Biology and Genetics, Bilkent University, 06800 Ankara, Turkey \\ ${ }^{\mathrm{c}}$ Bilkent University Genetics and Biotechnology Research Center (BilGen), Bilkent University, 06800 Ankara, Turkey
}

\section{A $\quad R \quad T$ I C C L E I I N F}

\section{Article history:}

Received 13 June 2014

Received in revised form

15 September 2014

Accepted 16 September 2014

Available online 20 September 2014

\section{Keywords}

Diarylpyrazole

Quinoline

Cytotoxicity

Autophagy

Apoptosis

\begin{abstract}
A B S T R A C T
We synthesized a series of novel amide derivatives of 5-( $p$-tolyl)-1-(quinolin-2-yl)pyrazole-3-carboxylic acid and assessed their antiproliferative activities against three human cancer cell lines (Huh7, human liver; MCF7, breast and HCT116, colon carcinoma cell lines) with the sulforhodamine B assay. Compound 4j with 2-chloro-4-pyridinyl group in the amide part exhibited promising cytotoxic activity against all cell lines with $\mathrm{IC}_{50}$ values of $1.6 \mu \mathrm{M}, 3.3 \mu \mathrm{M}$ and $1.1 \mu \mathrm{M}$ for Huh7, MCF7 and HCT116 cells, respectively, and produced dramatic cell cycle arrest at SubG1/G1 phase as an indicator of apoptotic cell death induction. On the basis of their high potency in cellular environment, these straightforward pyrazole-3carboxamide derivatives may possess potential in the design of more potent compounds for intervention with cancer cell proliferation.
\end{abstract}

๑) 2014 Elsevier Masson SAS. All rights reserved.

\section{Introduction}

Pyrazole and its derivatives have been widely studied for development of new therapeutics for various diseases including cancer $[1,2]$. In the last decade, many researchers have reported a large series of pyrazole derivatives having promising anticancer activities [3-11], indicating the use of pyrazole motif as a powerful tool for novel anticancer drug development. Many reports indicated that highly potent and efficient anticancer activity was observable when one of the aryl rings in diarylpyrazole core was substituted by other heterocycles possessing nitrogen and/or sulfur [2]. Among the reported studies, 4-quinolinylpyrazoles, 4quinolinylimidazoles, 4-quinoxalinylpyrazoles and 4-([1,2,4]triazolo[1,5-a]pyridin-6-yl)pyrazoles showed promising antiproliferative properties by inhibiting transforming growth factor- $\beta$ type 1 receptor kinase, also known as activin receptor-like kinase 5 (ALK5) [12-15]. Moreover, pyrazole-5-carboxylate [10,16], pyrazole-5-carboxamide [4] and pyrazole-5-carbohydrazide [6,8,9,11] derivatives were also shown to have a significant anticancer

\footnotetext{
* Corresponding author.

E-mail addresses: ebanoglu@gmail.com, banoglu@gazi.edu.tr (E. Banoglu).
}

activity against A549 lung cancer cell lines by inducing apoptosis or autophagy. Therefore, a wide range of information provided in the literature presents an ample opportunity for further investigation of pyrazole derivatives for the discovery of novel anticancer therapeutics. Hence, inspired by the promising results of current research on anticancer pyrazole derivatives, we have designed and synthesized a number of novel 5-(p-tolyl)-1-(quinolin-2-yl)-1Hpyrazole-3-carboxylic acid amides in rationale to previously reported potent ALK5 inhibitors and evaluated the effects of these compounds for their antiproliferative potential against different cancer cell lines using sulforhodamine B (SRB) assay. The target compounds $\mathbf{4 a}-\mathbf{0}$ were designed by replacing the 3,4diarylpyrazole motif in ALK5 inhibitors with 1,5-diarylpyrazole while having a quinolin-2-yl substitution at $C(5)$ of pyrazole with subsequent modifications at $\mathrm{C}(3)$-carboxamide chain to examine their effect on the biological activity (Fig. 1).

\section{Results and discussion}

\subsection{Chemistry}

The 1-(quinolin-2-yl)-5-(4-methylphenyl)pyrazol-3-carboxa mides $(\mathbf{4 a}-\mathbf{o})$ studied in this communication were synthesized 
<smiles>Cc1cccc(-c2nn(C(=S)Nc3cccc(C(N)=O)c3)cc2-c2ccc3ncccc3c2)n1</smiles><smiles>Cc1cccc(-c2nn(C(=S)Nc3ccccc3)cc2-c2ccnc3ccccc23)n1</smiles><smiles>Cc1cccc(-c2[nH]c(CNc3cccc(C#N)c3)nc2-c2ccc3nccnc3c2)n1</smiles>

$3(\mathrm{IN}-1166)$<smiles>[R]NC(=O)c1cc(-c2ccc(C)cc2)n(-c2ccc3ccccc3n2)n1</smiles>

$\mathrm{R}=$ pyridinyl groups (pyridinyl)piperazine groups

Fig. 1. Several ALK5 inhibitors with antiproliferative activities (1-3) under development, and the general structure of the synthesized compounds (4).

as outlined in Scheme 1. All compounds were purified by automated flash chromatography and checked for purity by elemental analysis and UPLC before being tested in biological assays (purity was $>97 \%$ ). The structures of these compounds were confirmed by high-resolution mass spectrometry (HRMS), elemental analysis, IR, ${ }^{13} \mathrm{C}$ NMR and ${ }^{1} \mathrm{H}$ NMR spectral data. As shown in Scheme 1, the synthesis of methyl 4-(4-methylphenyl)2,4-dioxobutanoate (1) was carried out by Claisen condensation of the commercially available acetophenone with dimethyl oxalate in the presence of a strong base [17]. The methyl ester of the 1-(quinolin-2-yl)-5-(4-methylphenyl)pyrazole-3-carboxylic acid was then conveniently synthesized by condensation of the diketo ester (1) with 2-hydrazinylquinoline (2) in methanol in the presence of 0.5 eq $\mathrm{HCl}$, which was subsequently hydrolyzed to free carboxylic acid (3) as described previously [18]. The final amide derivatives were produced either by reaction of the acyl

chloride of $\mathbf{3}$ with appropriate amines $(\mathbf{4} \mathbf{j}-\mathbf{m})$ or by using $\mathrm{N}$ ethyl-N'-(3-dimethylaminopropyl)carbodiimide hydrochloride $(E D C)$ as the carboxyl group activator $(\mathbf{4 a}-\mathbf{i}, \mathbf{4 n}-\mathbf{0})$. Therefore, we aimed to trace a tentative structure-activity relationship (SAR) profile for potential antiproliferative agents by modification of the carboxyl side chain of the starting intermediate $\mathbf{3}$ through amidation with various amines of different size, basicity and hydrophobicity.

\subsection{Biological evaluation}

In order to determine the potential anticancer activity of the obtained pyrazole carboxamides $(\mathbf{4 a}-\mathbf{o})$, we evaluated their cytotoxic activity on three different cancer cell lines including human liver (Huh7), breast (MCF7) and colon (HCT116) carcinoma cells by SRB assay for determining the $\mathrm{IC}_{50}$ values [19]. The compounds were bioactive in all three of the cancer cell lines with $\mathrm{IC}_{50}$ values in micromolar ranges (Table 1). In this study, Camptothecin (CPT) was included as an experimental positive control. The cytotoxic activities of $\mathbf{4 c}-\mathbf{h}, \mathbf{4 k}-\mathbf{o}$ having various substituents such as bromine, chlorine, trifluoromethyl, methoxy and nitrile in the pyridine ring were compared with that of the unsubstituted pyridine derivatives $\mathbf{4 a}-\mathbf{b}$ and $\mathbf{4 i - \mathbf { j }}$ as discussed below.

All amide derivatives (4a-o) inhibited cell proliferation with $\mathrm{IC}_{50}$ values in the range of $1.1-79.5 \mu \mathrm{M}$ as shown in Table 1 . The compound $\mathbf{4} \mathbf{j}$ bearing 2-chloro-4-pyridinyl group in the amide part of 1,5-diarypyrazole-3-carboxamide core displayed the most potent growth inhibitory activity against all cell lines $\left(\mathrm{IC}_{50}=1.6 \mu \mathrm{M}\right.$ for Huh7, $3.3 \mu \mathrm{M}$ for MCF7, and $1.1 \mu \mathrm{M}$ for HCT116 cells). When there is no substitution (4i) or 3-bromo substitution (4k) at 4pyridinyl, the cytotoxicity was significantly decreased on all cell lines with $\mathrm{IC}_{50}$ values between $8 \mu \mathrm{M}$ and $15.5 \mu \mathrm{M}$ (Table 1 ). Furthermore, when a methylene linker was inserted between the pyridine ring and carboxamide part disrupting the conjugation (4o), the cytotoxic activity again decreased with $\mathrm{IC}_{50}$ values of 11.2-19.0 $\mu \mathrm{M}$ for all cell lines. Compound 4n having 2-methoxy-3pyridinyl substituent demonstrated much better cytotoxic activity against Huh7 cells ( $\mathrm{IC}_{50}=7.9 \mu \mathrm{M}$ ) as compared to MCF7 and

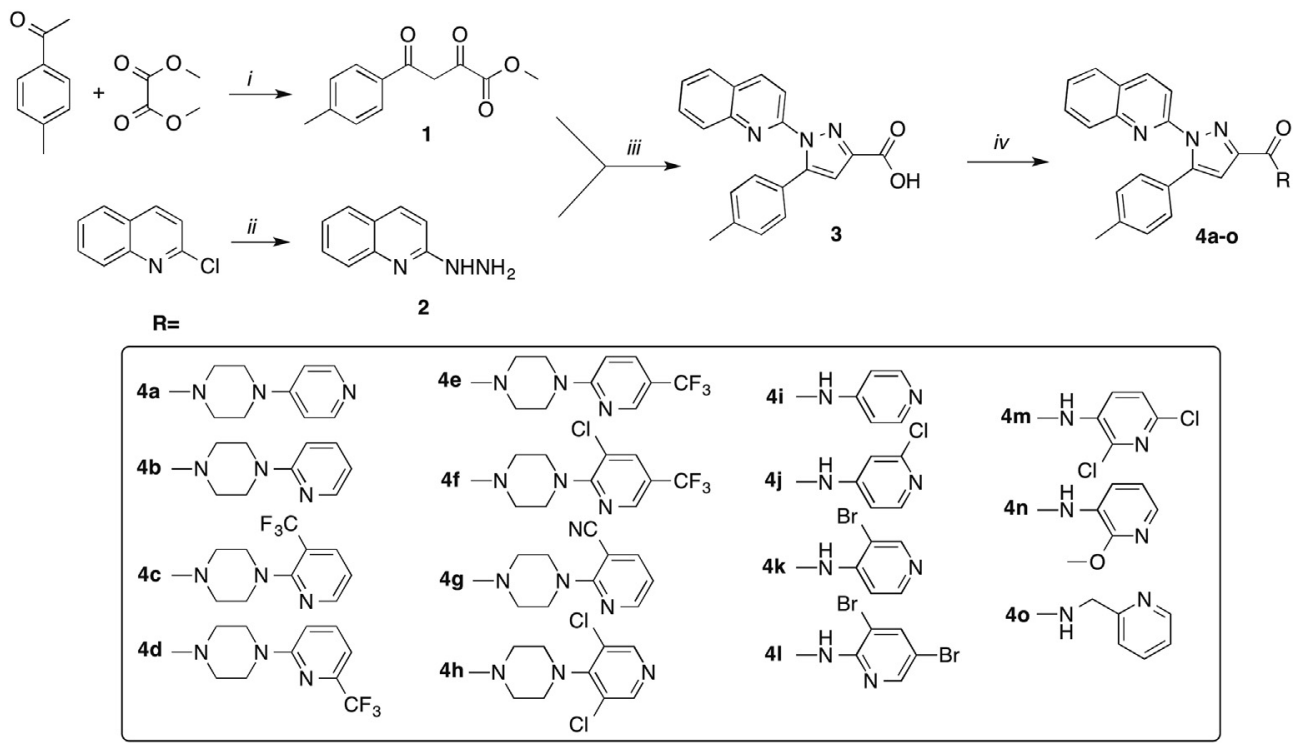

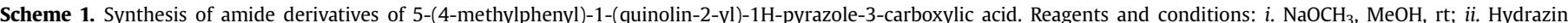

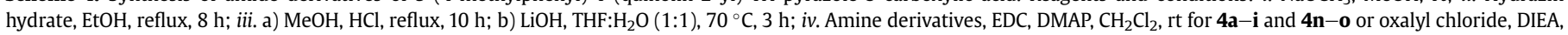
$\mathrm{CH}_{2} \mathrm{Cl}_{2}$, rt for $\mathbf{4 j}-\mathbf{m}$. 
Table 1

$\mathrm{IC}_{50}$ values in $\mu \mathrm{M}$ concentrations for $\mathbf{4 a}-\mathbf{o}$ with $72 \mathrm{~h}$ of treatment. ${ }^{\mathrm{a}}$

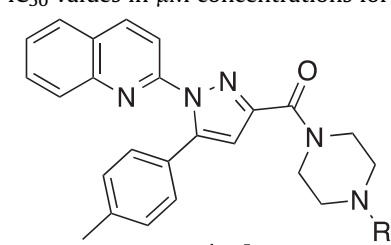

$4 a-h$

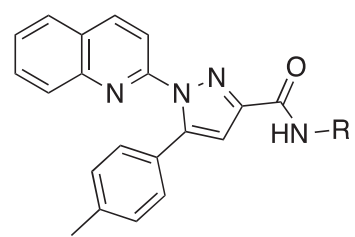

4i-o

\begin{tabular}{|c|c|c|c|c|}
\hline Cmpd. No & $\mathrm{R}$ & Huh7 & MCF7 & HCT116 \\
\hline $4 \mathbf{a}$ & (pyridin-4-yl)piperazine & $7.8 \pm 0.5$ & $4.7 \pm 0.5$ & $7.1 \pm 1.0$ \\
\hline $4 b$ & (pyridin-2-yl)piperazine & $4.8 \pm 2.0$ & $12.0 \pm 1.3$ & $5.1 \pm 1.1$ \\
\hline 4c & (3- $\mathrm{CF}_{3}$-pyridin-2-yl)piperazine & $12.7 \pm 0.2$ & $5.8 \pm 0.5$ & $9.7 \pm 1.7$ \\
\hline 4d & (6- $\mathrm{CF}_{3}$-pyridin-2-yl)piperazine & $10.2 \pm 2.2$ & $11.4 \pm 1.5$ & $9.4 \pm 2.5$ \\
\hline $4 e$ & (5-CF - -pyridin-2-yl)piperazine & $20.9 \pm 7.0$ & $44.7 \pm 24$ & $17.0 \pm 2.2$ \\
\hline $4 f$ & $\begin{array}{l}\text { (3-Cl-5- } \mathrm{CF}_{3}-\text { pyridin-2-yl) } \\
\text { piperazine }\end{array}$ & $8.0 \pm 1.8$ & $48.0 \pm 7.5$ & $13.3 \pm 1.1$ \\
\hline $4 g$ & (3-CN-pyridin-2-yl)piperazine & $21.5 \pm 2.2$ & $79.5 \pm 25$ & $39.4 \pm 3.0$ \\
\hline $4 h$ & (3,5-diCl-pyridin-4-yl)piperazine & $4.6 \pm 1.9$ & $9.7 \pm 0.3$ & $4.8 \pm 1.0$ \\
\hline $4 i$ & pyridin-4-yl & $8.0 \pm 1.9$ & $15.4 \pm 0.6$ & $8.1 \pm 2.2$ \\
\hline $4 \mathbf{j}$ & 2-Cl-pyridin-4-yl & $1.6 \pm 0.2$ & $3.3 \pm 0.9$ & $1.1 \pm 1.0$ \\
\hline $4 k$ & 3-Br-pyridin-4-yl & $13.1 \pm 0.1$ & $11.0 \pm 1.7$ & $15.5 \pm 0.6$ \\
\hline 41 & 3,5-diBr-pyridin-2-yl & $11.5 \pm 0.2$ & $16.9 \pm 2.5$ & $9.6 \pm 0.6$ \\
\hline $4 m$ & 2,6-diCl-pyridin-3-yl & $14.0 \pm 0.8$ & $12.7 \pm 0.05$ & $7.9 \pm 1.5$ \\
\hline $4 n$ & 2-OCH${ }_{3}$-pyridin-3-yl & $7.9 \pm 2.3$ & $30.2 \pm 8$ & $15.7 \pm 2.1$ \\
\hline 40 & pyridin-3-ylmethyl & $14.1 \pm 1.0$ & $19.0 \pm 0.7$ & $11.2 \pm 0.8$ \\
\hline CPT & & 0.004 & 0.0006 & 0.00015 \\
\hline
\end{tabular}

${ }^{a} \mathrm{IC}_{50}$ values were calculated from the cell growth inhibition percentages obtained with five different concentrations and data obtained were expressed as means of \pm SD.

HCT116 with $\mathrm{IC}_{50}$ values of 30.2 and $15.7 \mu \mathrm{M}$, respectively. Meanwhile, derivatives having 2,6-dichloro-3-pyridinyl (4m) and 3,5dibromo-2-pyridinyl (41) in the carboxamide part showed preferable activity for HCT116 ( IC $_{50}=7.9$ and $9.6 \mu \mathrm{M}$, respectively) with regard to Huh7 and MCF7 cells (Table 1 ).

For carboxamides having (pyridinyl)piperazine side chain, the (pyridin-4-yl)piperazine (4a), (pyridin-2-yl)piperazine (4b) and (3,5-dichloropyridin-4-yl)piperazine (4h) derivatives were the most active ones for their cytotoxic activity with differentially selective $\mathrm{IC}_{50}$ values with less than $5 \mu \mathrm{M}$ in some cell lines. For instance, MCF7 cells were found more sensitive to $\mathbf{4 a}$ $\left(\mathrm{IC}_{50}=4.7 \mu \mathrm{M}\right)$ while the Huh7 and HCT116 cells were more sensitive towards $\mathbf{4 b}$ and $\mathbf{4 h}$ ( $\mathrm{IC}_{50}$ of 4.8 and $5.1 \mu \mathrm{M}$ for $\mathbf{4 b} ; 4.6$ and $4.8 \mu \mathrm{M}$ for $\mathbf{4 h}$, respectively). We also investigated the effect of $\mathrm{CF}_{3}$ substituent on (pyridine-2-yl)piperazines. The (3- $\mathrm{CF}_{3}$-pyridin-2-yl) piperazine $(\mathbf{4 c})$ resulted in a better cytotoxicity against MCF7 cells ( $\mathrm{IC}_{50}$ of $5.8 \mu \mathrm{M}$ ), while $6-\mathrm{CF}_{3}$-pyridin-2-yl derivative (4d) was equally active against all cell lines with $\mathrm{IC}_{50}$ values in the range of 9.4-11.4 $\mu \mathrm{M}$. However, a diminished activity was observable with 5- $\mathrm{CF}_{3}$-pyridin-2-yl derivative $\left(4 \mathrm{e} \mathrm{IC}_{50}=17-44.7 \mu \mathrm{M}\right)$. Moreover, inclusion of chlorine at 3 position of pyridine ring in $4 \mathbf{e}$ producing 4f improved the cytotoxic activity towards Huh7 cells $(8.0 \mu \mathrm{M}$ vs. $20.9 \mu \mathrm{M})$. 3-Cyanopyridin-2-yl (4g) derivative was the least active molecule within the (pyridine-2-yl)piperazine series ( $\mathrm{IC}_{50}$ values of 21.5-79.5 $\mu \mathrm{M}$ ).

Recent studies have shown several diarylpyrazole derivatives resembling the general structure of present work possess ALK5, FLT3, ERK and B-raf kinase inhibitory activities suggesting that the kinase inhibition may play a role for the observed cytotoxicity of present compounds [12-15,20,21]. Therefore, in order to investigate the mechanism of action, and the kinase inhibitory profile of this new class of compounds, compound $\mathbf{4 j}$ with the highest potency on all cancer cell lines was tested at a single dose concentration of $10 \mu \mathrm{M}$ over a panel of 140 kinases (Table S1, Supporting Material) using a radioactive $\left({ }^{33} \mathrm{P}\right.$-ATP) filter-binding assay at
International Center for Kinase Profiling (University of Dundee, Scotland). As shown in Table S1, compound $\mathbf{4 j}$ has shown small inhibitory potency for some of kinases in the series with an inhibition percentage of $20-30 \%$ at the testing dose. The insignificant potency of $\mathbf{4} \mathbf{j}$ over a panel of kinase enzymes cannot justify for its strong and broad spectrum anticancer activity, and this suggests the presence of other underlying mechanisms that control the activity of this new compound against cancer cells. We also analyzed the effect of $4 \mathbf{j}(10 \mu \mathrm{M})$ on tubulin polymerization, and again, no inhibitory effect on tubulin polymerization was observed (data not shown).

\subsubsection{Effects of the $\mathbf{4 a}, \mathbf{4 j}$ and $\mathbf{4 o}$ on the morphology of Huh7 cells}

A series of selected active compounds (4a, $\mathbf{4 j}$ and $\mathbf{4 0}$ ) were examined to determine whether the decrease in cell viability/ number was caused by apoptosis. First, the effect of selected compounds was analyzed on their cell morphology with light microscopy. Human liver cancer cells (Huh7) were treated with $\mathbf{4 a}, \mathbf{4 j}$ and 40 at their $\mathrm{IC}_{50}$ values obtained upon $72 \mathrm{~h}$ of incubation (Table 1) in comparison with DMSO controls. As shown in Fig. 2(A) under inverted microscopy, all three compounds induced cell death with various morphologies including formation of intracytoplasmic vacuoles to indicate whether the observed cell death was caused by the induction of autophagy. It is also known that a cell that is undergoing apoptosis demonstrates nuclear condensation and DNA fragmentation, which can be detected by staining with Hoechst 33258 and fluorescence microscopy. In treatment of Huh7 cells with each compound at $\mathrm{IC}_{50}$ concentrations, we observed an apparent morphological change, such as nuclear condensation and fragmentation in the cells (Fig. 2(B)), which was in parallel with their cell cycle analysis (see below Fig. 3).

\subsubsection{Effects of $\mathbf{4 a}, \mathbf{4 j}$ and $\mathbf{4 o}$ on cell cycle arrest in Huh-7 and} Mahlavu HCC cells

Intervention with deregulated cell cycle progression in cancer cells correlates well with the inhibition of cell proliferation and apoptosis, and targeting the cell cycle has been a growing area as a new approach for cancer therapy [22,23]. Indeed, $\mathbf{4 a}, \mathbf{4 j}$ and $\mathbf{4 o}$ induced a dose-dependent inhibition of cell growth implying that these compounds may affect the cell cycle. As shown in Fig. 3, changes of the cell cycle profile induced by $\mathbf{4 a}, \mathbf{4 j}$ and $\mathbf{4 0}$ were studied using flow cytometry. Cells were harvested on $48 \mathrm{~h}$ after compound treatment at their $\mathrm{IC}_{50}$ concentrations and analyzed for the distribution of subG1, G0/G1, S and G2/M phases of the cell cycle. Normally, healthy well-differentiated HCC cell lines would be $60-70 \%$ in G1 phase, $20 \%$ in S phase, and 20\% in G2-M phase. Our results revealed that compound $\mathbf{4} \mathbf{j}$ showed dramatic cell cycle arrest in SubG1/G1 phase in Huh7 and Mahlavu cell lines, which is an indicator of apoptotic cell death induction. On the other hand, compound 4a also caused minor cell cycle arrest at SubG1/G1 phase in Mahlavu cell line. SubG1/G1 cell cycle arrest is not only reported with apoptosis but also reported to be associated with autophagy [24]. To determine if the compounds were involved in autophagic processes, western blot analysis of the classical autophagosome marker, microtubule-associated protein light chain 3 (LC3), in Huh7 cells was done. During autophagy LC3 is cleaved to its cytosolic form LC3-1. Lipidation leads to the LC3-2 form, which becomes associated with the autophagosomes. Conversion of LC3-1 to LC3-2 is therefore a marker for the autophagosome formation [25]. As shown in Fig. 4, LC3-2 levels by 72 h increased significantly for 4a and 4o, while there was no LC3-1 to LC3-2 conversion with $\mathbf{4 j}$. Since the Western blot results indicated autophagy induction by $\mathbf{4 a}$ and 4o, together we suggest that $4 \mathbf{a}$ and 4o's cytotoxic bioactivities may involve combined actions of autophagy and apoptosis. 


\section{A}
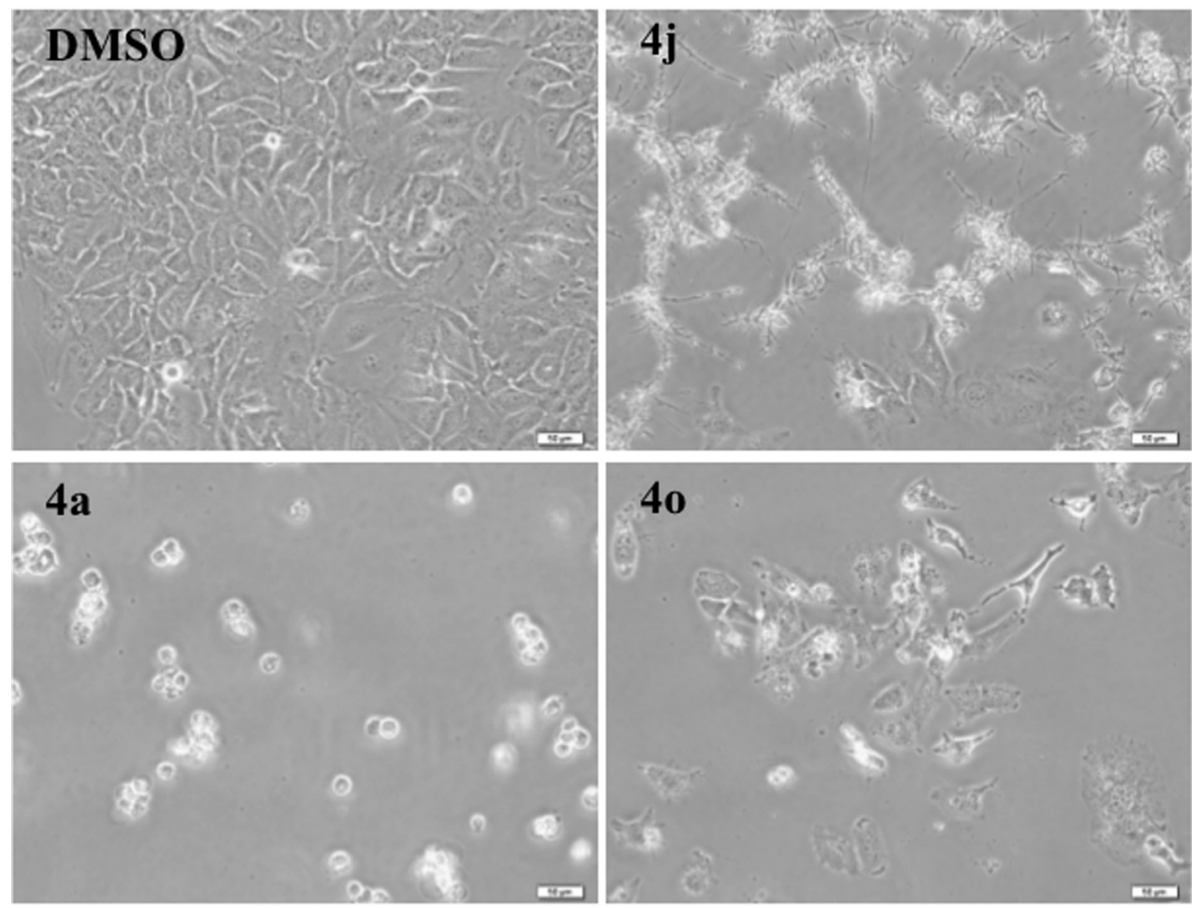

B
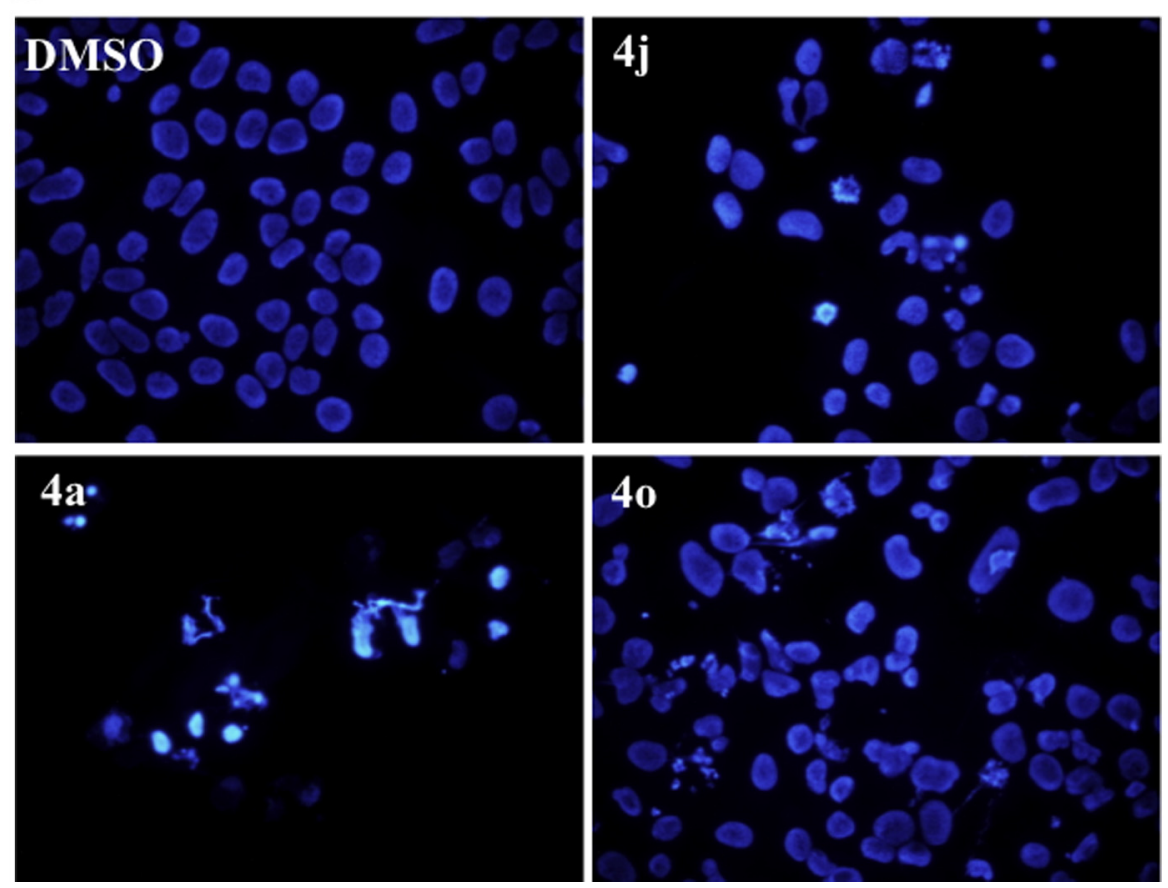

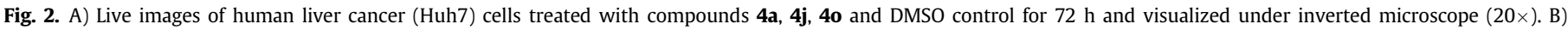

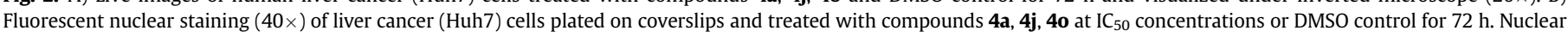
Hoechst 33258 stain (Sigma) was used to stain the cells.

\section{Conclusion}

In this communication, a series of 1-(quinolin-2-yl)-5-(4methylphenyl)pyrazole-3-carboxylic acid amides has been synthesized and evaluated for their antiproliferative activities against three selected human cancer cell lines. The preliminary SAR in this series of compounds have been established and discussed. The compound $\mathbf{4} \mathbf{j}$ had the lowest $\mathrm{IC}_{50}$ concentration in all cell lines
$\left(\mathrm{IC}_{50}=1.1-3.3 \mu \mathrm{M}\right)$ by inducing apoptosis with significant cell cycle arrest at SubG1/G1 phase in Mahlavu and Huh7 cell lines. In addition, compound $4 \mathbf{a}$ with considerable $\mathrm{IC}_{50}$ values against all cells $(4.7-7.8 \mu \mathrm{M})$ significantly induced autophagy in Huh7 cells. Therefore, these results simply imply that compounds $\mathbf{4 a}$ and $\mathbf{4 j}$ could be good lead candidates for further development, and slight structural modifications of these derivatives may yield prospective anticancer agents for breast, liver and colon cancer cells. 

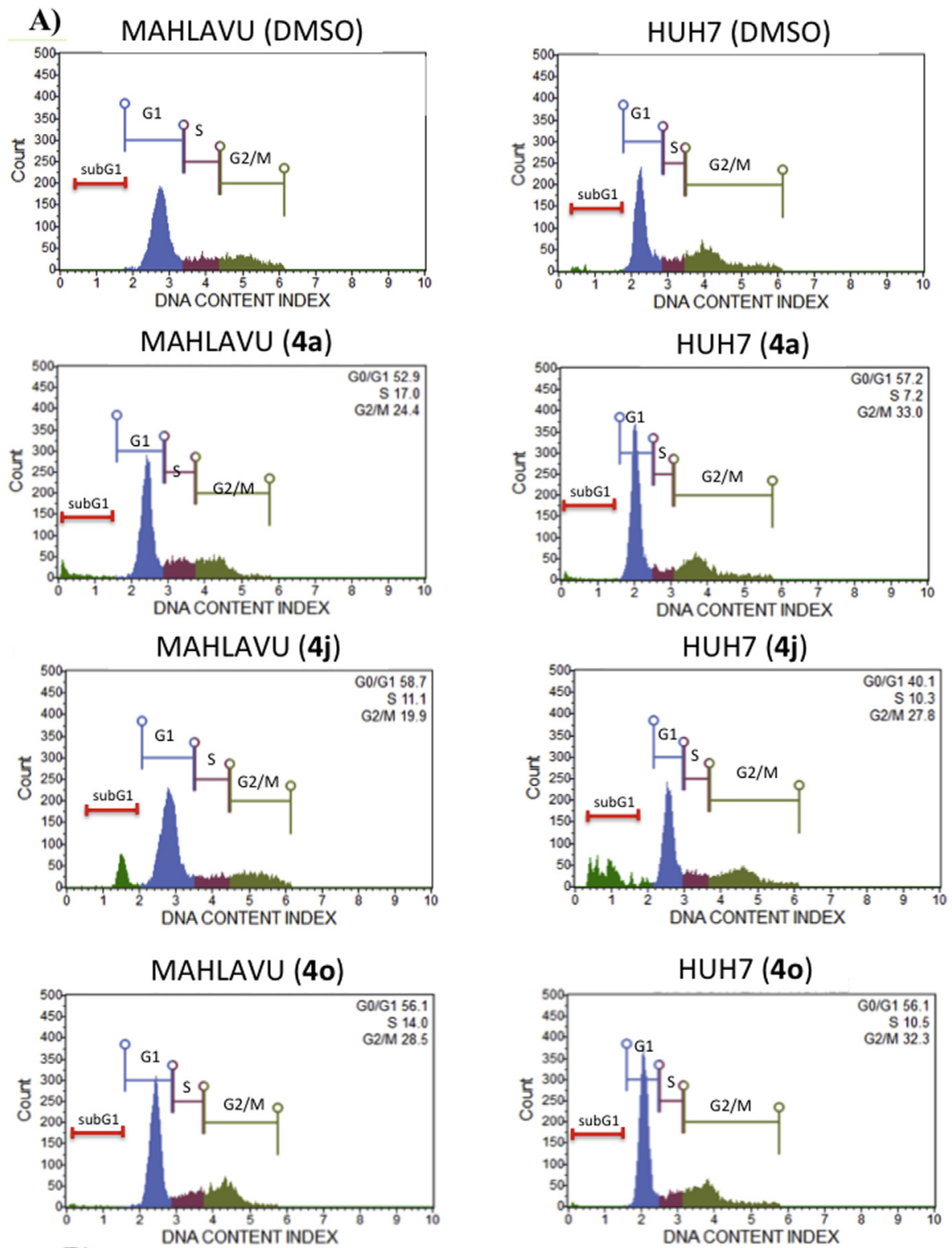

B)

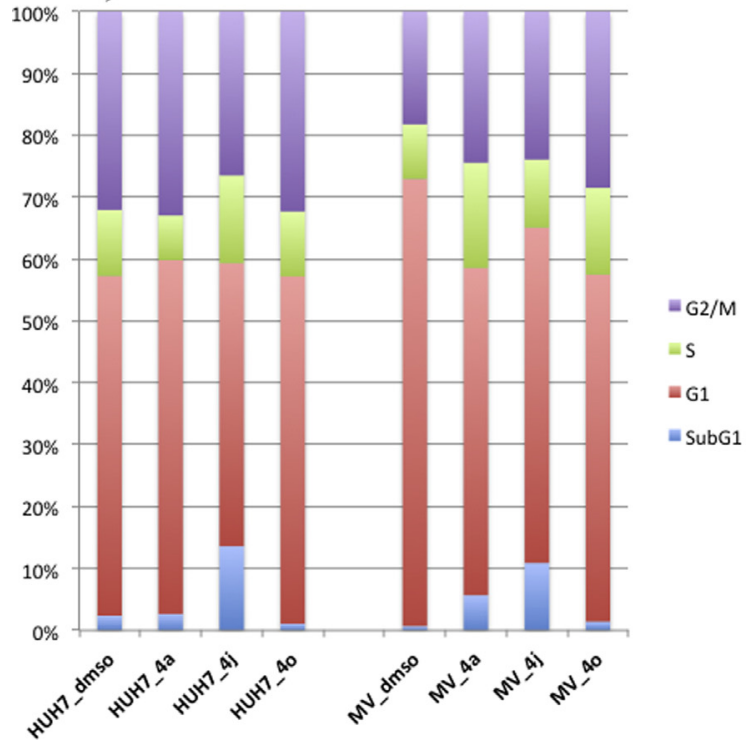

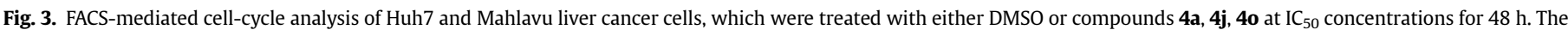

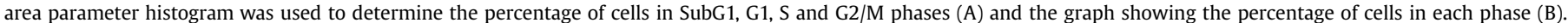



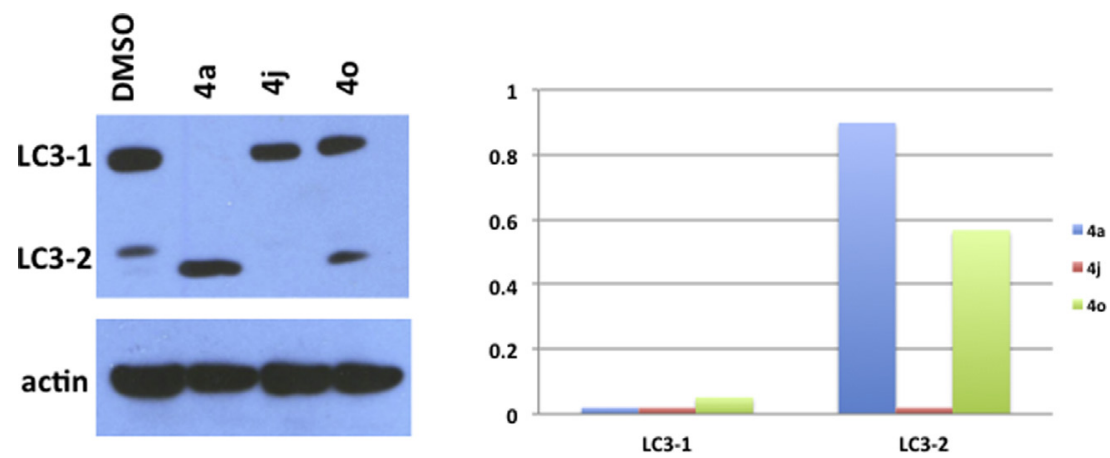

Fig. 4. Western blot analysis of LC3-1 to LC3-2 conversion in human liver (Huh7) cancer cells treated with the compounds $\mathbf{4 a}$, $\mathbf{4 j}$, $4 \mathbf{4 0}$ or DMSO control for $72 \mathrm{~h}$.

\section{Experimental section}

\subsection{Chemistry}

${ }^{1} \mathrm{H}$ and ${ }^{13} \mathrm{C}$ NMR spectra were recorded in $\mathrm{CDCl}_{3}$ or DMSO- $d_{6}$ on a Varian Mercury $400 \mathrm{MHz}$ High Performance Digital FT-NMR spectrometer using tetramethylsilane as the internal standard at the NMR facility of Faculty of Pharmacy, Ankara University. All chemical shifts were recorded as $\delta$ (ppm). High-resolution mass spectra data (HRMS) were collected in-house using a Waters LCT Premier XE Mass Spectrometer (high sensitivity orthogonal acceleration time-of-flight instrument) operating in ESI (+) method, also coupled to an AQUITY Ultra Performance Liquid Chromatography system (Waters Corporation, Milford, MA, USA). Melting points were determined with an SMP-II Digital Melting Point Apparatus (Schorpp Geaetetechnik, Germany), and are uncorrected. IR spectra were obtained using a Perkin Elmer Spectrum 400 FTIR/FTNIR spectrometer equipped with a Universal ATR Sampling Accessory and only carbonyl stretching frequencies were given. Flash chromatography was performed with a Combiflash ${ }^{\mathbb{R}} \mathrm{Rf}$ automated flash chromatography system with RediSep columns (Teledyne-Isco, Lincoln, NE, USA) using hexane-ethyl acetate, dichloromethane-ethyl acetate and dichloromethane-methanol solvent gradients. The purity of the final compounds was determined to be $>97 \%$ by UPLC with UV detector and elemental analysis (LECO 932 CHNS analyzer, Leco Corporation, St. Joseph, MI). Elemental analyses indicated by the symbols of the elements were within $\pm 0.4 \%$ of the theoretical values. Methyl 4-(4-methylphenyl)-2,4dioxobutanoate (1) was obtained by the reaction of $4^{\prime}$-methylacetophenone with dimethyloxalate as described previously [17]. 2-Hydrazinoquinoline (2) was synthesized by the reaction of 2chloroquinoline with hydrazine hydrate [26].

\subsubsection{5-(4-Methylphenyl)-1-quinolin-2-yl-1H-pyrazol-3-carboxylic} acid (3)

To a mixture of methyl 4-(4-methylphenyl)-2,4-dioxobutanoate (1) $(5.44 \mathrm{mmol})$ in methanol $(15 \mathrm{ml})$, 2-hydrazinoquinoline (2) (5.71 mmol) and concentrated $\mathrm{HCl}(2.72 \mathrm{mmol})$ were added and heated at reflux temperature for $10 \mathrm{~h}$. The resulting solution was cooled, the precipitate was collected by filtration and recrystallized from methanol to produce methyl 5-(4-methylphenyl)-1-quinolin2-yl-1H-pyrazol-3-carboxylate (3a) in $90 \%$ yield; Mp $152-153{ }^{\circ} \mathrm{C}$. IR (ATR): $1717 \mathrm{~cm}^{-1} .{ }^{1} \mathrm{H}$ NMR $\left(\mathrm{CDCl}_{3}\right): \delta 2.34(3 \mathrm{H}, \mathrm{s}), 3.98(3 \mathrm{H}, \mathrm{s})$, $7.06(1 \mathrm{H}, \mathrm{s}), 7.10(2 \mathrm{H}, \mathrm{d}, J=8.0 \mathrm{~Hz}), 7.20(2 \mathrm{H}, \mathrm{d}, J=8.4 \mathrm{~Hz}), 7.54-7.57$ $(1 \mathrm{H}, \mathrm{m}), 7.66-7.70(2 \mathrm{H}, \mathrm{m}), 7.81-7.84(2 \mathrm{H}, \mathrm{m}), 8.22(1 \mathrm{H}, \mathrm{d}$, $J=8.4 \mathrm{~Hz}) .{ }^{13} \mathrm{C} \mathrm{NMR}\left(\mathrm{CDCl}_{3}\right): \delta 21.56,52.49,111.02,117.63,127.46$, $127.65,127.74,129.11,129.19,129.55,130.55,138.89,138.98,144.91$, 146.05, 146.62, 150.86, 163.02. HRMS $(\mathrm{m} / \mathrm{z}):[\mathrm{M}+\mathrm{H}]^{+}$calcd for
$\mathrm{C}_{21} \mathrm{H}_{18} \mathrm{~N}_{3} \mathrm{O}_{2}$ : 344.1399; found: 344.1400. Anal. Calcd for $\mathrm{C}_{21} \mathrm{H}_{17} \mathrm{~N}_{3} \mathrm{O}_{2}$ : C, 73.45; H, 4.99; N, 12.24; found $\mathrm{C}, 73.42 ; \mathrm{H}, 4.92 ; \mathrm{N}$, 12.23 .

The obtained ester derivative ( $5 \mathrm{mmol}$ ) was subsequently hydrolyzed to corresponding acid (3) in THF/water (1:1) with $\mathrm{LiOH} \cdot \mathrm{H}_{2} \mathrm{O}(15 \mathrm{mmol})$ by heating at $70{ }^{\circ} \mathrm{C}$ for $3 \mathrm{~h}$. The reaction mixture was poured into water and acidified with $6 \mathrm{~N} \mathrm{HCl}$, precipitate was collected by filtration and washed with water, and used in the synthesis of amide derivatives. Yield 99\%; Mp $228{ }^{\circ} \mathrm{C}$. IR (ATR): $1719 \mathrm{~cm}^{-1} .{ }^{1} \mathrm{H} \mathrm{NMR}\left(\mathrm{CDCl}_{3}\right): \delta 2.36(3 \mathrm{H}, \mathrm{s}), 7.11(1 \mathrm{H}, \mathrm{s}), 7.12$ $(2 \mathrm{H}, \mathrm{d}, J=8.0 \mathrm{~Hz}), 7.22(2 \mathrm{H}, \mathrm{d}, J=8.4 \mathrm{~Hz}), 7.56-7.60(1 \mathrm{H}, \mathrm{m})$, $7.68-7.72(2 \mathrm{H}, \mathrm{m}), 7.82-7.86(2 \mathrm{H}, \mathrm{m}), 8.25(1 \mathrm{H}, \mathrm{d}, J=8.8 \mathrm{~Hz})$. HRMS $(\mathrm{m} / \mathrm{z}):[\mathrm{M}+\mathrm{H}]^{+}$calcd for $\mathrm{C}_{20} \mathrm{H}_{16} \mathrm{~N}_{3} \mathrm{O}_{2}$ : 330.1243; found: 330.1226 .

\subsubsection{General synthesis of amide derivatives}

4.1.2.1. Method A. To a mixture of the carboxylic acid derivative $\mathbf{3}$ ( $1 \mathrm{mmol}$ ) in $10 \mathrm{ml} \mathrm{CH}_{2} \mathrm{Cl}_{2}$, the appropriate amine (1.1 mmol), 4dimethylaminopyridine (DMAP) $(0.2 \mathrm{mmol})$ and 1-ethyl-3-(3dimethylaminopropyl)carbodiimide (EDC) (1.1 mmol) were added, and stirred at room temperature overnight. The reaction mixture was diluted with $\mathrm{CH}_{2} \mathrm{Cl}_{2}$ and washed with $1 \mathrm{~N} \mathrm{HCl}$ $(3 \times 20 \mathrm{ml}), 5 \% \mathrm{NaHCO}_{3}(3 \times 20 \mathrm{ml})$, and brine. After drying over $\mathrm{Na}_{2} \mathrm{SO}_{4}$, solvent was evaporated under reduced pressure and the crude product was purified by flash chromatography.

4.1.2.2. Method B. To the solution of $3(1 \mathrm{mmol})$ in $\mathrm{CH}_{2} \mathrm{Cl}_{2}(20 \mathrm{ml})$, oxalyl chloride $(1.5 \mathrm{mmol})$ and catalytic amount of DMF (three drops) were added at $0{ }^{\circ} \mathrm{C}$, and stirred for $30 \mathrm{~min}$. After completion of the reaction, the mixture was concentrated to remove excess of oxalyl chloride. To the solution of acid chloride in fresh $\mathrm{CH}_{2} \mathrm{Cl}_{2}$ $(25 \mathrm{ml}), \mathrm{N}, \mathrm{N}$-diisopropylethylamine (DIEA) $(2 \mathrm{mmol})$ was added followed by amine $(1.1 \mathrm{mmol})$ at $0{ }^{\circ} \mathrm{C}$ and allowed to stir at RT. After completion of the reaction, reaction mixture was washed with water $(3 \times 30 \mathrm{ml})$ and brine $(3 \times 30 \mathrm{ml})$, and then the combined organic layer was dried over $\mathrm{Na}_{2} \mathrm{SO}_{4}$ and then evaporated to dryness and the crude product was purified by flash chromatography.

\subsubsection{2-[5-(4-Methylphenyl)-3-[4-(pyridin-4-yl)piperazine-1-} carbonyl]-1H-pyrazol-1-yllquinoline (4a)

Prepared from $3(1.2 \mathrm{mmol})$ and 1-(pyridin-4-yl)piperazine (1.3 mmol) using method A. Flash chromatography $\mathrm{CH}_{2} \mathrm{Cl}_{2}: \mathrm{MeOH}$; yield 70\%; Mp $200{ }^{\circ} \mathrm{C}$. IR (ATR): $1634 \mathrm{~cm}^{-1}$. ${ }^{1} \mathrm{H} \mathrm{NMR}\left(\mathrm{CDCl}_{3}\right): \delta 2.36$ (3H, s), 3.46-3.49 (4H, m), $3.99(2 \mathrm{H}, \mathrm{bt}), 4.36(2 \mathrm{H}, \mathrm{bt}), 6.68(2 \mathrm{H}, \mathrm{d}$, $J=6.0 \mathrm{~Hz}), 6.98(1 \mathrm{H}, \mathrm{s}), 7.12(2 \mathrm{H}, \mathrm{d}, J=8.4 \mathrm{~Hz}), 7.23(2 \mathrm{H}, \mathrm{d}$, $J=8.0 \mathrm{~Hz}), 7.56-7.61(2 \mathrm{H}, \mathrm{m}), 7.69-7.73(1 \mathrm{H}, \mathrm{m}), 7.82-7.86(2 \mathrm{H}, \mathrm{m})$, $8.23(1 \mathrm{H}, \mathrm{d}, J=8.4 \mathrm{~Hz}), 8.30-8.32(2 \mathrm{H}, \mathrm{m})$. HRMS $(\mathrm{m} / \mathrm{z}):[\mathrm{M}+\mathrm{H}]^{+}$ calcd for $\mathrm{C}_{29} \mathrm{H}_{27} \mathrm{~N}_{6} \mathrm{O}$ : 475.2246; found: 475.2234 . 
4.1.4. 2-[5-(4-Methylphenyl)-3-[4-(pyridin-2-yl)piperazine-1carbonyl]-1H-pyrazol-1-yl]quinoline (4b)

Prepared from 3 (1.2 $\mathrm{mmol})$ and 1-(2-pyridyl)piperazine (1.3 mmol) using method A. Flash chromatography $\mathrm{CH}_{2} \mathrm{Cl}_{2}$ :EtOAc; yield $86 \%$; Mp $141-142{ }^{\circ} \mathrm{C}$. IR (ATR): $1614 \mathrm{~cm}^{-1}$. ${ }^{1} \mathrm{H} \mathrm{NMR}\left(\mathrm{CDCl}_{3}\right)$ : $\delta 2.37$ (3H, s), 3.68 (4H, bt), 3.97 (2H, bt), 4.29 (2H, bt), 6.65-6.69 $(2 \mathrm{H}, \mathrm{m}), 6.95(1 \mathrm{H}, \mathrm{s}), 7.12(2 \mathrm{H}, \mathrm{d}, J=8.0 \mathrm{~Hz}), 7.24(2 \mathrm{H}, \mathrm{d}, J=8.4 \mathrm{~Hz})$, 7.51-7.58 $(2 \mathrm{H}, \mathrm{m}), 7.66(1 \mathrm{H}, \mathrm{d}, J=8.8 \mathrm{~Hz}), 7.69-7.71(1 \mathrm{H}, \mathrm{m}), 7.78$ $(1 \mathrm{H}, \mathrm{d}, J=8.4 \mathrm{~Hz}), 7.84(1 \mathrm{H}, \mathrm{d}, J=8.0 \mathrm{~Hz}), 8.21-8.24(2 \mathrm{H}, \mathrm{m}) .{ }^{13} \mathrm{C}$ NMR $\left(\mathrm{CDCl}_{3}\right): \delta 21.31,42.32,45.15,45.75,46.81,107.19,111.23$, $113.74,117.04,127.00,127.21,127.46,127.60,128.82,128.93,129.13$, $130.25,137.61,138.43,138.61,145.12,146.33,148.02,148.10,150.84$, 159.22, 162,62. HRMS $(m / z)$ : $[\mathrm{M}+\mathrm{H}]^{+}$calcd for $\mathrm{C}_{29} \mathrm{H}_{27} \mathrm{~N}_{6} \mathrm{O}$ : 475.2243; found: 475.2246. Anal. Calcd for $\mathrm{C}_{29} \mathrm{H}_{26} \mathrm{~N}_{6} \mathrm{O}$ : C, 73.40; $\mathrm{H}$, 5.52; N, 17.71; found C, 73.61; H, 5.65; N, 17.84.

\subsubsection{2-[5-(4-Methylphenyl)-3-\{4-[3-(trifluoromethyl)pyridin-2-}

yl]piperazine-1-carbonyl\}-1H-pyrazol-1-yl]quinoline (4c)

Prepared from $3(1.2 \mathrm{mmol})$ and 1-[3-(trifluoromethyl)-2pyridinyl]piperazine $(1.3 \mathrm{mmol})$ using method A. Flash chromatography $\mathrm{CH}_{2} \mathrm{Cl}_{2}$ :EtOAc; yield 70\%; Mp $111{ }^{\circ} \mathrm{C}$. IR (ATR): $1624 \mathrm{~cm}^{-1}$. ${ }^{1} \mathrm{H} \mathrm{NMR}\left(\mathrm{CDCl}_{3}\right): \delta 2.36(3 \mathrm{H}, \mathrm{s}), 3.36-3.42(4 \mathrm{H}, \mathrm{m}), 3.99(2 \mathrm{H}, \mathrm{bt})$, $4.27(2 \mathrm{H}, \mathrm{bt}), 6.93(1 \mathrm{H}, \mathrm{s}), 7.04(1 \mathrm{H}, \mathrm{dd}, J=7.6$ and $4.8 \mathrm{~Hz}), 7.12(2 \mathrm{H}$, $\mathrm{d}, J=8.4 \mathrm{~Hz}), 7.24(2 \mathrm{H}, \mathrm{d}, J=8.4 \mathrm{~Hz}), 7.53-7.57(1 \mathrm{H}, \mathrm{m}), 7.66-7.70$ $(2 \mathrm{H}, \mathrm{m}), 7.78(1 \mathrm{H}, \mathrm{d}, J=8.4 \mathrm{~Hz}), 7.83(1 \mathrm{H}, \mathrm{d}, J=8.4 \mathrm{~Hz}), 7.90(1 \mathrm{H}, \mathrm{dd}$, $J=7.6$ and $1.6 \mathrm{~Hz}), 8.22(1 \mathrm{H}, \mathrm{d}, J=8.4 \mathrm{~Hz}), 8.46(1 \mathrm{H}, \mathrm{dd}, J=4.8$ and $1.6 \mathrm{~Hz}) .{ }^{13} \mathrm{C} \mathrm{NMR}\left(\mathrm{CDCl}_{3}\right): \delta 21.30,42.54,47.21,50.64,51.26,111.13$, 117.08, 117.35, ( $\left.{ }^{2} J_{\mathrm{C}-\mathrm{F}}=31 \mathrm{~Hz}\right), 117.46,123.87\left({ }^{1} J_{\mathrm{C}-\mathrm{F}}=271 \mathrm{~Hz}\right)$, 126.96, 127.21, 127.44, 127.64, 128.81, 128.94, 129.13, 130.21, 137.27 $\left({ }^{3} J_{C-F}=5 \mathrm{~Hz}\right), 138.39,138.60,145.08,146.32,148.15,150.86,151.09$, 159.50, 162.72. HRMS $(m / z)$ : $[\mathrm{M}+\mathrm{H}]^{+}$calcd for $\mathrm{C}_{30} \mathrm{H}_{26} \mathrm{~F}_{3} \mathrm{~N}_{6} \mathrm{O}$ : 543.2120; found: 543.2145. Anal. Calcd for $\mathrm{C}_{30} \mathrm{H}_{25} \mathrm{~F}_{3} \mathrm{~N}_{6} \mathrm{O}$ : C, 66.41; H, 4.64; N, 15.49; found C, 66.82; H, 4.78; N, 15.68 .

\subsubsection{2-[5-(4-Methylphenyl)-3-\{4-[6-(trifluoromethyl)pyridin-2-} yllpiperazine-1-carbonyl\}-1H-pyrazol-1-yllquinoline $(\mathbf{4 d})$

Prepared from 3 (1.2 mmol) and 1-[6-(trifluoromethyl)pyridin2-yl]piperazine (1.3 mmol) using method A. Flash chromatography $\mathrm{CH}_{2} \mathrm{Cl}_{2}$ :EtOAc; yield $79 \%$; Mp $177^{\circ} \mathrm{C}$. IR (ATR): $1616 \mathrm{~cm}^{-1}$. ${ }^{1} \mathrm{H}$ NMR $\left(\mathrm{CDCl}_{3}\right): \delta 2.37(3 \mathrm{H}, \mathrm{s}), 3.72-3.78(4 \mathrm{H}, \mathrm{m}), 3.97(2 \mathrm{H}, \mathrm{bt}), 4.32(2 \mathrm{H}$, bt), $6.81(1 \mathrm{H}, \mathrm{d}, J=8.8 \mathrm{~Hz}), 6.97(1 \mathrm{H}, \mathrm{s}), 6.99(1 \mathrm{H}, \mathrm{d}, J=7.2 \mathrm{~Hz}), 7.12$ $(2 \mathrm{H}, \mathrm{d}, J=8.0 \mathrm{~Hz}), 7.24(2 \mathrm{H}, \mathrm{d}, J=8.4 \mathrm{~Hz}), 7.55-7.65(3 \mathrm{H}, \mathrm{m})$, $7.68-7.72(1 \mathrm{H}, \mathrm{m}), 7.80-7.86(2 \mathrm{H}, \mathrm{m}), 8.24(1 \mathrm{H}, \mathrm{d}, J=8.8 \mathrm{~Hz}) \cdot{ }^{13} \mathrm{C}$ NMR $\left(\mathrm{CDCl}_{3}\right): \delta \quad 21.30,42.19, \quad 44.72, \quad 45.17, \quad 46.61,109.34$ $\left({ }^{3} J_{C-F}=3 \mathrm{~Hz}\right), 109.55,111.31,117.07,121.54\left({ }^{1} J_{C}-\mathrm{F}=272 \mathrm{~Hz}\right), 127.04$, 127.24, 127.47, 127.52, 128.85, 128.92, 129.16, 130.28, 138.49, 138.65, $145.15,146.37,146.46\left({ }^{2} J_{C-F}=34 \mathrm{~Hz}\right), 148.02,150.80,158.55,162.60$. HRMS $(m / z):[\mathrm{M}+\mathrm{H}]^{+}$calcd for $\mathrm{C}_{30} \mathrm{H}_{26} \mathrm{~F}_{3} \mathrm{~N}_{6} \mathrm{O}$ : 543.2120; found: 543.2136. Anal. Calcd for $\mathrm{C}_{30} \mathrm{H}_{25} \mathrm{~F}_{3} \mathrm{~N}_{6} \mathrm{O}$ : C, 66.41; H, 4.64; N, 15.49; found $\mathrm{C}, 66.50 ; \mathrm{H}, 4.86 ; \mathrm{N}, 15.65$.

\subsubsection{2-[5-(4-Methylphenyl)-3-\{4-[5-(trifluoromethyl)pyridin-2-} yl]piperazine-1-carbonyl\}-1H-pyrazol-1-yl]quinoline (4e)

Prepared from 3 (1.2 mmol) and 1-[5-(trifluoromethyl)pyridin2-yl]piperazine $(1.3 \mathrm{mmol})$ using the method A. Flash chromatography hexane:EtOAc; yield $72 \%$; Mp $217^{\circ} \mathrm{C}$. IR (ATR): $1633 \mathrm{~cm}^{-1} .{ }^{1} \mathrm{H}$ $\operatorname{NMR}\left(\mathrm{CDCl}_{3}\right): \delta 2.37(3 \mathrm{H}, \mathrm{s}), 3.79(4 \mathrm{H}, \mathrm{m}), 3.97(2 \mathrm{H}, \mathrm{bt}), 4.32(2 \mathrm{H}, \mathrm{bt})$, $6.67(1 \mathrm{H}, \mathrm{d}, J=9.2 \mathrm{~Hz}), 6.97(1 \mathrm{H}, \mathrm{s}), 7.12(2 \mathrm{H}, \mathrm{d}, J=8.0 \mathrm{~Hz}), 7.24(2 \mathrm{H}$, $\mathrm{d}, J=8.0 \mathrm{~Hz}), 7.55-7.59(1 \mathrm{H}, \mathrm{m}), 7.62(1 \mathrm{H}, \mathrm{d}, J=8.8 \mathrm{~Hz}), 7.65-7.72$ $(2 \mathrm{H}, \mathrm{m}), 7.80-7.86(2 \mathrm{H}, \mathrm{m}), 8.23(1 \mathrm{H}, \mathrm{d}, J=8.4 \mathrm{~Hz}), 8.42(1 \mathrm{H}, \mathrm{s}) .{ }^{13} \mathrm{C}$ NMR $\left(\mathrm{CDCl}_{3}\right): \delta 21.30,42.20,44.49,45.11,46.58,105.64,111.30$, $115.67\left({ }^{2} J_{\mathrm{C}-\mathrm{F}}=33 \mathrm{~Hz}\right), 117.08,124.50\left({ }^{1} J_{\mathrm{C}-\mathrm{F}}=268 \mathrm{~Hz}\right) 127.09,127.24$, 127.47, 128.87, 128.91, 129.14, 130.32, 134.64, ( $\left.{ }^{3} J_{C-F}: 3 \mathrm{~Hz}\right), 138.53$, 138.64, 145.19, 145.77 ( $\left.{ }^{3} \mathrm{~J}_{\mathrm{C}-\mathrm{F}}=5 \mathrm{~Hz}\right), 146.37,147.97,150.78,160.17$, 162.63. HRMS $(m / z)$ : $[\mathrm{M}+\mathrm{H}]^{+}$calcd for $\mathrm{C}_{30} \mathrm{H}_{26} \mathrm{~F}_{3} \mathrm{~N}_{6} \mathrm{O}$ : 543.2120; found: 543.2133. Anal. Calcd for $\mathrm{C}_{30} \mathrm{H}_{25} \mathrm{~F}_{3} \mathrm{~N}_{6} \mathrm{O}$ : C, 66.41; $\mathrm{H}, 4.64 ; \mathrm{N}$, 15.49; found C, 66.43; $\mathrm{H}, 4.83 ; \mathrm{N}, 15.46$.

\subsubsection{2-(3-\{4-[3-Chloro-5-(trifluoromethyl)pyridin-2-yl]} piperazine-1-carbonyl\}-5-[(4-methylphenyl)-1H-pyrazol-1-yl] quinoline (4f)

Prepared from 3 (1.2 mmol) and 1-[3-chloro-5-(trifluoromethyl) pyridin-2-yllpiperazine $(1.3 \mathrm{mmol})$ using the method A. Flash chromatography hexane:EtOAc; yield $82 \%$; Mp $154{ }^{\circ} \mathrm{C}$. IR (ATR): $1628 \mathrm{~cm}^{-1}$. ${ }^{1} \mathrm{H}$ NMR $\left(\mathrm{CDCl}_{3}\right): \delta 2.37(3 \mathrm{H}, \mathrm{s}), 3.59-3.64(4 \mathrm{H}, \mathrm{m}), 4.00$ $(2 \mathrm{H}, \mathrm{bt}), 4.33(2 \mathrm{H}, \mathrm{bt}), 6.96(1 \mathrm{H}, \mathrm{s}), 7.12(2 \mathrm{H}, \mathrm{d}, J=8.0 \mathrm{~Hz}), 7.24(2 \mathrm{H}$, $\mathrm{d}, J=7.6 \mathrm{~Hz}), 7.55-7.58(1 \mathrm{H}, \mathrm{m}), 7.63(1 \mathrm{H}, \mathrm{d}, J=8.8 \mathrm{~Hz}), 7.68-7.72$ $(1 \mathrm{H}, \mathrm{m}), 7.79-7.85(3 \mathrm{H}, \mathrm{m}), 8.23(1 \mathrm{H}, \mathrm{d}, J=8.8 \mathrm{~Hz}), 8.41(1 \mathrm{H}, \mathrm{s}) .{ }^{13} \mathrm{C}$ NMR $\left(\mathrm{CDCl}_{3}\right): \delta$ 21.30, 42.34, 46.93, 48.53, 49.14, 111.23, 117.12, 120.99, $123.20\left({ }^{1} J_{\mathrm{C}-\mathrm{F}}=270 \mathrm{~Hz}\right), 127.04,127.37\left({ }^{2} J_{\mathrm{C}-\mathrm{F}}=29 \mathrm{~Hz}\right)$, $127.46,128.85,128.91,129.15,130.28,136.08,138.48,138.62,143.03$ $\left({ }^{3} J_{C-F}=4 \mathrm{~Hz}\right), 145.15,146.37,148.04,150.81,159.64,162.68$. HRMS (m/z): $[\mathrm{M}+\mathrm{H}]^{+}$calcd for $\mathrm{C}_{30} \mathrm{H}_{25} \mathrm{ClF}_{3} \mathrm{~N}_{6} \mathrm{O}$ : 577.1730; found: 577.1757 . Anal. Calcd for $\mathrm{C}_{30} \mathrm{H}_{24} \mathrm{ClF}_{3} \mathrm{~N}_{6} \mathrm{O}$ : C, 62.45; $\mathrm{H}, 4.19$; N, 14.57; found $\mathrm{C}$, 62.59; H, 4.30; N, 14.73.

\subsubsection{2-\{4-[5-(4-Methylphenyl)-1-(quinolin-2-yl)-1H-pyrazole-3-} carbonyl]piperazine-1-yl\}pyridine-3-carbonitrile (4g)

Prepared from 3 (1.2 mmol) and 2-(piperazin-1-yl)pyridine-3carbonitrile $(1.3 \mathrm{mmol})$ using method A. Flash chromatography $\mathrm{CH}_{2} \mathrm{Cl}_{2}$ :EtOAc; yield 82\%; Mp $241{ }^{\circ} \mathrm{C}$. IR (ATR): $1635 \mathrm{~cm}^{-1} .{ }^{1} \mathrm{H}$ NMR $\left(\mathrm{CDCl}_{3}\right): \delta 2.37(3 \mathrm{H}, \mathrm{s}), 3.81-3.85(4 \mathrm{H}, \mathrm{m}), 4.01(2 \mathrm{H}, \mathrm{bt}), 4.36(2 \mathrm{H}$, bt), $6.82(1 \mathrm{H}$, dd, $J=7.6$ and $4.8 \mathrm{~Hz}), 6.97(1 \mathrm{H}, \mathrm{s}), 7.12(2 \mathrm{H}, \mathrm{d}$, $J=8.0 \mathrm{~Hz}), 7.24(2 \mathrm{H}, \mathrm{d}, J=8.4 \mathrm{~Hz}), 7.54-7.58(1 \mathrm{H}, \mathrm{m}), 7.65(1 \mathrm{H}, \mathrm{d}$, $J=8.4 \mathrm{~Hz}), 7.69-7.71(1 \mathrm{H}, \mathrm{m}), 7.78-7.85(3 \mathrm{H}, \mathrm{m}), 8.23(1 \mathrm{H}, \mathrm{d}$, $J=8.4 \mathrm{~Hz}), 8.38(1 \mathrm{H}, \mathrm{dd}, J=4.8$ and $2.0 \mathrm{~Hz}) \cdot{ }^{13} \mathrm{C}$ NMR $\left(\mathrm{CDCl}_{3}\right)$ : $\delta$ 21.30, 42.38, 46.84, 47.75, 48.82, 95.38, 111.34, 114.59, 117.06, $117.85,127.02,127.24,127.46,127.55,128.84,128.93,129.16,130.25$, $138.45,138.65,143.82,145.15,146.35,147.98,150.79,151.88,160.63$, 162.63. HRMS $(m / z):[\mathrm{M}+\mathrm{H}]^{+}$calcd for $\mathrm{C}_{30} \mathrm{H}_{26} \mathrm{~N}_{7} \mathrm{O}$ : 500.2199 ; found: 500.2198. Anal. Calcd for $\mathrm{C}_{30} \mathrm{H}_{25} \mathrm{~N}_{7} \mathrm{O}$ : C, 72.13; $\mathrm{H}, 5.04 ; \mathrm{N}$, 19.63; found C, 71.94; H, 5.30; N, 19.22.

\subsubsection{2-\{3-[4-(3,5-Dichloropyridin-4-yl)piperazine-1-carbonyl]- 5-(4-methylphenyl)-1H-pyrazol-1-yl\}quinoline (4h)}

Prepared from 3 (1.2 mmol) and 1-[3,5-dichloropyridin-4-yl] piperazine $(1.3 \mathrm{mmol})$ using method A. Flash chromatography $\mathrm{CH}_{2} \mathrm{Cl}_{2}$ :EtOAc; yield $72 \%$; Mp $217{ }^{\circ} \mathrm{C}$. IR (ATR): $1614 \mathrm{~cm}^{-1} .{ }^{1} \mathrm{H}$ NMR $\left(\mathrm{CDCl}_{3}\right): \delta 2.36(3 \mathrm{H}, \mathrm{s}), 3.42-3.49(4 \mathrm{H}, \mathrm{m}), 4.00(2 \mathrm{H}, \mathrm{bt}), 4.31(2 \mathrm{H}$, bt), $6.96(1 \mathrm{H}, \mathrm{s}), 7.12(2 \mathrm{H}, \mathrm{d}, J=8.4 \mathrm{~Hz}), 7.23(2 \mathrm{H}, \mathrm{d}, J=8.0 \mathrm{~Hz})$, $7.55-7.58(1 \mathrm{H}, \mathrm{m}), 7.61(1 \mathrm{H}, \mathrm{d}, J=8.4 \mathrm{~Hz}), 7.67-7.72(1 \mathrm{H}, \mathrm{m})$, $7.80-7.85(2 \mathrm{H}, \mathrm{m}), 8.22(1 \mathrm{H}, \mathrm{d}, J=8.8 \mathrm{~Hz}), 8.37(2 \mathrm{H}, \mathrm{s}) .{ }^{13} \mathrm{C} \mathrm{NMR}$ $\left(\mathrm{CDCl}_{3}\right): \delta 21.31,43.29,48.02,50.04,50.68,111.16,117.17,127.07$ 127.24, 127.46, 127.47, 128.63, 128.87, 128.91, 129.16, 130.29, 138.51, 138.63, 145.17, 146.38, 148.05, 149.23, 150.80, 150.96, 162.79. HRMS (m/z): $[\mathrm{M}+\mathrm{H}]^{+}$calcd for $\mathrm{C}_{29} \mathrm{H}_{25} \mathrm{Cl}_{2} \mathrm{~N}_{6} \mathrm{O}$ : 543.1467; found: 543.1459 . Anal. Calcd for $\mathrm{C}_{29} \mathrm{H}_{24} \mathrm{Cl}_{2} \mathrm{~N}_{6} \mathrm{O}$ : C, 64.09; $\mathrm{H}, 4.45 ; \mathrm{N}, 15.46$; found $\mathrm{C}$, 64.31; H, 4.57; N, 15.67 .

\subsubsection{5-(4-Methylphenyl)-N-(pyridin-4-yl)-1-(quinolin-2-yl)-1H- pyrazole-3-carboxamide $(\mathbf{4 i})$}

Prepared from 3 (1.2 mmol) and pyridin-4-amine (1.3 mmol) using method A. Flash chromatography $\mathrm{CH}_{2} \mathrm{Cl}_{2}$ :EtOAc; yield $78 \%$; $\mathrm{Mp} 184^{\circ} \mathrm{C}$. IR (ATR): $1701 \mathrm{~cm}^{-1} .{ }^{1} \mathrm{H}$ NMR $\left(\mathrm{CDCl}_{3}\right): \delta 2.36(3 \mathrm{H}, \mathrm{s}), 7.13$ $(2 \mathrm{H}, \mathrm{d}, J=8.0 \mathrm{~Hz}), 7.17(1 \mathrm{H}, \mathrm{s}), 7.20(2 \mathrm{H}, \mathrm{d}, J=8.4 \mathrm{~Hz}), 7.43(1 \mathrm{H}, \mathrm{d}$, $J=8.4 \mathrm{~Hz}), 7.61-7.65(1 \mathrm{H}, \mathrm{m}), 7.69-7.71(2 \mathrm{H}, \mathrm{m}), 7.76-7.80(1 \mathrm{H}, \mathrm{m})$, $7.88(1 \mathrm{H}, \mathrm{d}, J=8.0 \mathrm{~Hz}), 8.00(1 \mathrm{H}, \mathrm{d}, J=8.8 \mathrm{~Hz}), 8.23(1 \mathrm{H}, \mathrm{d}$, $J=8.4 \mathrm{~Hz}), 8.55(2 \mathrm{H}, \mathrm{d}, J=6.4 \mathrm{~Hz}), 9.05(1 \mathrm{H}, \mathrm{s}) .{ }^{13} \mathrm{C} \mathrm{NMR}\left(\mathrm{CDCl}_{3}\right)$ : $\delta$ 21.31, 109.12, 113.62, 117.55, 126.76, 127.47, 127.59, 128.81, 129.19, 129.30, 130.69, 138.82, 139.09, 144.68, 146.67, 146.78, 147.28, 150.37, 
150.80, 160.06. HRMS $(m / z):[\mathrm{M}+\mathrm{H}]^{+}$calcd for $\mathrm{C}_{25} \mathrm{H}_{20} \mathrm{~N}_{5} \mathrm{O}$ : 406.1668; found: 406.1667. Anal. Calcd for $\mathrm{C}_{25} \mathrm{H}_{19} \mathrm{~N}_{5} \mathrm{O}$ : C, 74.06; $\mathrm{H}$, 4.72; N, 17.27; found C, 74.30; H, 5.00; N, 17.39.

\subsubsection{N-(2-Chloropyridin-4-yl)-5-(4-methylphenyl)-1-(quinolin-}

2-yl)-1H-pyrazol-3-carboxamide (4j)

Prepared from $3(1.2 \mathrm{mmol})$ and 2-chloropyridin-4-amine (1.3 mmol) using method B. Flash chromatography hexane:EtOAc; yield 63\%; Mp $190{ }^{\circ} \mathrm{C}$. IR (ATR): $1698 \mathrm{~cm}^{-1}$. ${ }^{1} \mathrm{H}$ NMR $\left(\mathrm{CDCl}_{3}\right): \delta 2.35$ $(3 \mathrm{H}, \mathrm{s}), 7.12(2 \mathrm{H}, \mathrm{d}, J=8.8 \mathrm{~Hz}), 7.15(1 \mathrm{H}, \mathrm{s}), 7.19(2 \mathrm{H}, \mathrm{d}, J=8.4 \mathrm{~Hz})$, $7.41(1 \mathrm{H}, \mathrm{d}, J=9.2 \mathrm{~Hz}), 7.55(1 \mathrm{H}, \mathrm{dd}, J=5.2$ and $2.0 \mathrm{~Hz}), 7.60-7.64$ $(1 \mathrm{H}, \mathrm{m}), 7.75-7.79(1 \mathrm{H}, \mathrm{m}), 7.82(1 \mathrm{H}, \mathrm{d}, J=2.0 \mathrm{~Hz}), 7.88(1 \mathrm{H}, \mathrm{d}$, $J=8.0 \mathrm{~Hz}), 7.99(1 \mathrm{H}, \mathrm{d}, J=8.8 \mathrm{~Hz}), 8.22(1 \mathrm{H}, \mathrm{d}, J=8.4 \mathrm{~Hz}), 8.29(1 \mathrm{H}$, $\mathrm{d}, J=5.2 \mathrm{~Hz}), 9.07(1 \mathrm{H}, \mathrm{s}) .{ }^{13} \mathrm{C} \mathrm{NMR}\left(\mathrm{CDCl}_{3}\right): \delta 21.34,109.14,112.51$, $113.48,117.53,126.58,127.49,127.60,127.67,128.80,129.25,129.28$, 130.76, 138.87, 139.22, 146.67, 146.80, 146.88, 150.25, 150.27, 152.50, 159.99. HRMS $(m / z):[\mathrm{M}+\mathrm{H}]^{+}$calcd for $\mathrm{C}_{25} \mathrm{H}_{19} \mathrm{ClN}_{5} \mathrm{O}: 440.1274$; found: 440.1278. Anal. Calcd for $\mathrm{C}_{25} \mathrm{H}_{18} \mathrm{ClN}_{5} \mathrm{O}: \mathrm{C}, 68.26 ; \mathrm{H}, 4.12 ; \mathrm{N}$, 15.92; found $\mathrm{C}, 68.51 ; \mathrm{H}, 4.31 ; \mathrm{N}, 15.98$.

4.1.13. N-(3-Bromopyridin-4-yl)-5-(4-methylphenyl)-1-(quinolin2-yl)-1H-pyrazol-3-carboxamide (4k)

Prepared from 3 (1.2 mmol) and 3-bromopyridin-4-amine (1.3 mmol) using method B. Flash chromatography hexane:EtOAc; yield 38\%; Mp $228{ }^{\circ} \mathrm{C}$. IR (ATR): $1703 \mathrm{~cm}^{-1}$. ${ }^{1} \mathrm{H}$ NMR $\left(\mathrm{CDCl}_{3}\right): \delta 2.37$ $(3 \mathrm{H}, \mathrm{s}), 7.12(2 \mathrm{H}, \mathrm{d}, J=8.4 \mathrm{~Hz}), 7.15(1 \mathrm{H}, \mathrm{s}), 7.23(2 \mathrm{H}, \mathrm{d}, J=8.0 \mathrm{~Hz})$, 7.57-7.61 $(1 \mathrm{H}, \mathrm{m}), 7.69-7.73(2 \mathrm{H}, \mathrm{m}), 7.81(1 \mathrm{H}, \mathrm{d}, J=8.0 \mathrm{~Hz}), 7.87$ $(1 \mathrm{H}, \mathrm{d}, J=8.0 \mathrm{~Hz}), 8.29(1 \mathrm{H}, \mathrm{d}, J=8.4 \mathrm{~Hz}), 8.48(1 \mathrm{H}, \mathrm{d}, J=5.6 \mathrm{~Hz})$, $8.60(1 \mathrm{H}, \mathrm{d}, J=5.6 \mathrm{~Hz}), 8.68(1 \mathrm{H}, \mathrm{s}), 9.74(1 \mathrm{H}, \mathrm{s}) .{ }^{13} \mathrm{C} \mathrm{NMR}\left(\mathrm{CDCl}_{3}\right)$ : $\delta 21.32,109.35,110.75,114.63,116.80,127.17,127.36,127.43,127.52$, $128.93,129.21,130.50,138.86,138.95,142.54,146.30,146.79,147.04$, 149.71, 150.45, 151.76, 160.07. HRMS $(m / z):[\mathrm{M}+\mathrm{H}]^{+}$calcd for $\mathrm{C}_{25} \mathrm{H}_{19} \mathrm{BrN}_{5} \mathrm{O}$ : 484.0773; found: 484.0777. Anal. Calcd for $\mathrm{C}_{25} \mathrm{H}_{18} \mathrm{BrN}_{5} \mathrm{O}$ : C, 61.99; H, 3.75; N, 14.46; found C, 62.17; H, 3.81; N, 14.89 .

\subsubsection{N-(3,5-Dibromopyridin-2-yl)-5-(4-methylphenyl)-1-}

(quinolin-2-yl)-1H-pyrazol-3-carboxamide (4l)

Prepared from 3 (1.2 mmol) and 3,5-dibromopyridin-2-amine (1.3 mmol) using method B. Flash chromatography hexane:EtOAc; yield $21 \%$; Mp $208{ }^{\circ} \mathrm{C}$. IR (ATR): $1714 \mathrm{~cm}^{-1}$. ${ }^{1} \mathrm{H} \mathrm{NMR}\left(\mathrm{CDCl}_{3}\right): \delta 2.37$ $(3 \mathrm{H}, \mathrm{s}), 7.12(2 \mathrm{H}, \mathrm{d}, J=8.0 \mathrm{~Hz}), 7.19(1 \mathrm{H}, \mathrm{s}), 7.23(2 \mathrm{H}, \mathrm{d}, J=7.6 \mathrm{~Hz})$, $7.59-7.61(1 \mathrm{H}, \mathrm{m}), 7.66(1 \mathrm{H}, \mathrm{d}, J=8.8 \mathrm{~Hz}), 7.71-7.75(1 \mathrm{H}, \mathrm{m})$, $7.85-7.88(2 \mathrm{H}, \mathrm{m}), 8.06(1 \mathrm{H}, \mathrm{d}, J=2.0 \mathrm{~Hz}), 8.27(1 \mathrm{H}, \mathrm{d}, J=8.4 \mathrm{~Hz})$, $8.54(1 \mathrm{H}, \mathrm{d}, J=2.0 \mathrm{~Hz}), 9.67(1 \mathrm{H}, \mathrm{s}) .{ }^{13} \mathrm{C} \mathrm{NMR}\left(\mathrm{CDCl}_{3}\right): \delta 21.31,109.56$, $111.45,114.85,117.03,127.22,127.32,127.39,127.50,128.91,128.94$, 129.24, 130.46, 138.76, 138.82, 143.00, 146.38, 146.82, 147.27, 147.37, 148.34, 150.55, 158.50. HRMS $(\mathrm{m} / \mathrm{z}):[\mathrm{M}+\mathrm{H}]^{+}$calcd for $\mathrm{C}_{25} \mathrm{H}_{18} \mathrm{Br}_{2} \mathrm{~N}_{5} \mathrm{O}$ : 561.9878; found: 561.9885. Anal. Calcd for $\mathrm{C}_{25} \mathrm{H}_{17} \mathrm{Br}_{2} \mathrm{~N}_{5} \mathrm{O}$ : C, 53.31; H, 3.04; N, 12.43; found C, 53.44; $\mathrm{H}, 3.26 ; \mathrm{N}$, 12.96 .

\subsubsection{N-(2,6-Dichloropyridin-3-yl)-5-(4-methylphenyl)-1-}

(quinolin-2-yl)-1H-pyrazol-3-carboxamide (4m)

Prepared from 3 (1.2 mmol) and 2,6-dichloropyridin-3-amine (1.3 mmol) using method B. Flash chromatography $\mathrm{CH}_{2} \mathrm{Cl}_{2}(100 \%)$; yield 35\%; Mp $247^{\circ} \mathrm{C}$. IR (ATR): $1691 \mathrm{~cm}^{-1}$. ${ }^{1} \mathrm{H}$ NMR $\left(\mathrm{CDCl}_{3}\right): \delta 2.37$ $(3 \mathrm{H}, \mathrm{s}), 7.12(2 \mathrm{H}, \mathrm{d}, J=8.0 \mathrm{~Hz}), 7.14(1 \mathrm{H}, \mathrm{s}), 7.24(2 \mathrm{H}, \mathrm{d}, J=7.6 \mathrm{~Hz})$, $7.34(1 \mathrm{H}, \mathrm{d}, J=8.8 \mathrm{~Hz}), 7.58-7.62(1 \mathrm{H}, \mathrm{m}), 7.68(1 \mathrm{H}, \mathrm{d}, J=8.8 \mathrm{~Hz})$, 7.70-7.74 (1H, m), 7.82-7.88 (2H, m), $8.28(1 \mathrm{H}, \mathrm{d}, J=8.8 \mathrm{~Hz}), 8.95$ $(1 \mathrm{H}, \mathrm{d}, J=8.8 \mathrm{~Hz}), 9.48(1 \mathrm{H}, \mathrm{s}){ }^{13} \mathrm{C}$ NMR $\left(\mathrm{CDCl}_{3}\right): \delta 21.32,109.18$, $116.93,123.74,127.13,127.40,127.44,127.53,128.91,128.97,129.22$, $130.51,130.92,131.24,138.60,138.87,138.94,143.22,146.35,146.74$, 146.98, 150.42, 150.99. HRMS $(\mathrm{m} / \mathrm{z}):[\mathrm{M}+\mathrm{H}]^{+}$calcd for $\mathrm{C}_{25} \mathrm{H}_{18} \mathrm{Cl}_{2} \mathrm{~N}_{5} \mathrm{O}$ : 474.0888; found: 478.0879. Anal. Calcd for
$\mathrm{C}_{25} \mathrm{H}_{17} \mathrm{Cl}_{2} \mathrm{~N}_{5} \mathrm{O}: \mathrm{C}, 63.30 ; \mathrm{H}, 3.61 ; \mathrm{N}, 14.76$; found $\mathrm{C}, 62.92 ; \mathrm{H}, 3.63 ; \mathrm{N}$, 14.63 .

4.1.16. $N$-(2-Methoxypyridin-3-yl)-5-(4-methylphenyl)-1(quinolin-2-yl)-1H-pyrazol-3-carboxamide (4n)

Prepared from $3(1.2 \mathrm{mmol})$ and 2-methoxypyridin-3-amine (1.3 mmol) using method A. Flash chromatography hexane:EtOAc; yield 75\%; Mp $193{ }^{\circ} \mathrm{C}$. IR (ATR): $1673 \mathrm{~cm}^{-1}$. ${ }^{1} \mathrm{H}$ NMR $\left(\mathrm{CDCl}_{3}\right): \delta 2.36$ $(3 \mathrm{H}, \mathrm{s}), 4.06(3 \mathrm{H}, \mathrm{s}), 6.95(1 \mathrm{H}, \mathrm{dd}, J=8.0$ and $4.8 \mathrm{~Hz}), 7.12(2 \mathrm{H}, \mathrm{d}$, $J=8.0 \mathrm{~Hz}), 7.14(1 \mathrm{H}, \mathrm{s}), 7.23(2 \mathrm{H}, \mathrm{d}, J=8.0 \mathrm{~Hz}), 7.58-7.63(2 \mathrm{H}, \mathrm{m})$, $7.72-7.76(1 \mathrm{H}, \mathrm{m}), 7.86-7.91(3 \mathrm{H}, \mathrm{m}), 8.27(1 \mathrm{H}, \mathrm{d}, J=8.0 \mathrm{~Hz}), 8.78$ $(1 \mathrm{H}, \mathrm{dd}, J=8.0$ and $2.0 \mathrm{~Hz}), 9.32(1 \mathrm{H}, \mathrm{s}) .{ }^{13} \mathrm{C} \mathrm{NMR}\left(\mathrm{CDCl}_{3}\right): \delta 21.31$, 53.75, 109.14, 117.24, 117.38, 122.76, 126.60, 127.27, 127.30, 127.40, $127.51,128.88,128.97,129.26,130.44,138.72,138.75,140.23,146.47$, 146.52, 147.82, 150.65, 153.43, 160.13. HRMS $(m / z):[\mathrm{M}+\mathrm{H}]^{+}$calcd for $\mathrm{C}_{26} \mathrm{H}_{22} \mathrm{~N}_{5} \mathrm{O}_{2}$ : 436.1774; found: 436.1775. Anal. Calcd for $\mathrm{C}_{26} \mathrm{H}_{21} \mathrm{~N}_{5} \mathrm{O}_{2}$ : C, 71.71; H, 4.86; N, 16.08; found C, 71.92; H, 5.22; N, 16.29 .

4.1.17. 5-(4-Methylphenyl)-N-(pyridin-3-ylmethyl)-1-(quinolin-2yl)-1H-pyrazol-3-carboxamide (4o)

Prepared from $3(1.2 \mathrm{mmol})$ and pyridin-3-ylmethanamine (1.3 mmol) using method A. Flash chromatography $\mathrm{CH}_{2} \mathrm{Cl}_{2}: \mathrm{MeOH}$; yield $81 \%$; Mp $134{ }^{\circ} \mathrm{C}$. IR (ATR): $1628 \mathrm{~cm}^{-1}$. ${ }^{1} \mathrm{H}$ NMR $\left(\mathrm{CDCl}_{3}\right): \delta 2.35$ $(3 \mathrm{H}, \mathrm{s}), 4.69(2 \mathrm{H}, \mathrm{d}, J=6.0 \mathrm{~Hz}), 7.10-7.12(3 \mathrm{H}, \mathrm{m}), 7.19(2 \mathrm{H}, \mathrm{d}$, $J=7.6 \mathrm{~Hz}), 7.27-7.29(1 \mathrm{H}, \mathrm{m}), 7.42(1 \mathrm{H}, \mathrm{d}, J=9.2 \mathrm{~Hz}), 7.47-7.50(1 \mathrm{H}$, bt), 7.57-7.60 $(1 \mathrm{H}, \mathrm{m}), 7.71-7.76(2 \mathrm{H}, \mathrm{m}), 7.84(1 \mathrm{H}, \mathrm{d}, J=8.4 \mathrm{~Hz})$, $7.92(1 \mathrm{H}, \mathrm{d}, J=8.8 \mathrm{~Hz}), 8.17(1 \mathrm{H}, \mathrm{d}, J=8.8 \mathrm{~Hz}), 8.54(1 \mathrm{H}, \mathrm{dd}$, $J=5.0 \mathrm{~Hz}$ and $J=1.4 \mathrm{~Hz}), 8.63(1 \mathrm{H}, \mathrm{d}, J=2.4 \mathrm{~Hz}) .{ }^{13} \mathrm{C} \mathrm{NMR}\left(\mathrm{CDCl}_{3}\right)$ : $\delta$ 21.29, 40.68, 109.01, 117.46, 123.55, 127.14, 127.33, 127.48, 128.81, 129.06, 129.28, 130.47, 133.94, 135.74, 138.63, 138.79, 146.16, 146.61, 147.54, 148.95, 149.36, 150.55, 161.81. HRMS $(m / z):[\mathrm{M}+\mathrm{H}]^{+}$calcd for $\mathrm{C}_{26} \mathrm{H}_{22} \mathrm{~N}_{5} \mathrm{O}$ : 420.1824; found: 420.1818. Anal. Calcd for $\mathrm{C}_{26} \mathrm{H}_{21} \mathrm{~N}_{5} \mathrm{O}$ : C, 74.44; H, 5.05; N, 16.70; found C, 74.49; H, 4.73; N, 16.64 .

\subsection{Biological studies}

Cell culture: Cell lines were obtained from the following sources and validated by STR analysis: Mahlavu [27], Huh7 (JCRB JCRB0403), HCT116 (ATCC CCL-247), MCF7 (ATCC HTB22). Cell lines were grown in Dulbecco's modified Eagle's medium (DMEM) supplemented with $10 \%$ fetal calf serum (FCS) and $50 \mathrm{mg} / \mathrm{ml}$ penicillin/ streptomycin. Each cell line was maintained in a humidified incubator at $37{ }^{\circ} \mathrm{C}$ supplied with $5 \% \mathrm{CO}_{2}$.

\subsubsection{Sulforhodamine $B$ (SRB) assay for cytotoxicity screening}

Human liver (Huh7), colon (HCT116) and breast (MCF7) cancer cells were inoculated (2000-3000 cells/well in $200 \mu \mathrm{L}$ ) in 96-well plates. The next day, the media were refreshed and the compounds dissolved in DMSO were applied in increasing concentrations of the compounds $(2.5-40 \mu \mathrm{M})$ and incubated. DMSO-only treated cells were used as negative controls (for $40 \mu \mathrm{M}$ compound concentration $0.2 \%$ DMSO, for $20 \mu \mathrm{M}$ compound $0.1 \%$ DMSO, for $10 \mu \mathrm{M}$ of compound $0.05 \%$ DMSO, for $5 \mu \mathrm{M}$ compound $0.025 \%$ DMSO, for $2.5 \mu \mathrm{M}$ of compound $0.012 \%$ DMSO was used as vehicle control). Camptothecin was used as positive control. At the 72 nd hour of treatment with compounds $\mathbf{4 a}-\mathbf{o}$ and the other drugs, the cancer cells were fixed with $100 \mu \mathrm{L}$ of $10 \%$ (w/v) trichloroacetic acid (TCA) and kept at $+4{ }^{\circ} \mathrm{C}$ in the dark for one hour. TCA fixation was terminated by washing the wells with $\mathrm{ddH}_{2} \mathrm{O}$ five times. Air-dried plates were stained with $0.4 \%$ sulforhodamine B (SRB) dissolved in $1 \%$ acetic acid solution for $10 \mathrm{~min}$ in the dark and at room temperature. The protein-bound and dried SRB dye was then solubilized with $10 \mathrm{mM}$ Tris-Base $\mathrm{pH}$ 8. The absorbance values were obtained at $515 \mathrm{~nm}$ in a 
microplate reader. The data normalized against DMSO only treated wells, which were used as controls in serial dilutions. In all experiments, a linear response was observed, with serial dilutions of the compounds and the drugs; $R^{2} \geq 0.9$. Data for anticancer activity were analyzed by one-way ANOVA and expressed as means of \pm SD.

\subsubsection{Hoechst stain}

Human liver cancer cells (Huh7) were inoculated on coverslips in 6-well plates for $24 \mathrm{~h}$. Then the cells were treated with IC $_{50}$ concentrations of the compounds for $72 \mathrm{~h}$. To determine nuclear condensation by Hoescht 33258 (Sigma-Aldrich) staining, cells were fixed with $1 \mathrm{ml}$ of cold methanol for $10 \mathrm{~min}$ after being washed twice with ice cold $1 \times$ PBS. Then the samples were incubated with $3 \mu \mathrm{g} / \mathrm{mL}$ of Hoescht for $5 \mathrm{~min}$ in darkness. The coverslips were then rinsed with distilled water, mounted on glass microscopic slides using 50\% glycerol, and examined under fluorescent microscopy $(40 \times)$.

\subsubsection{Western blotting}

Human liver cancer cells (Huh7) cells were treated with the compounds or DMSO control for $72 \mathrm{~h}$. Equal amounts of cell lysates were solubilized with $1 \times$ loading dye, SRA (or DTT). (Protein concentration of lysates was determined by the Bradford assay.) Then the lysates were denatured for $10 \mathrm{~min}$ in $100{ }^{\circ} \mathrm{C}$. $30 \mathrm{ng}$ of proteins were loaded to the gels. NuPAGE NOVEX pre-cast gel system was used for throughout the western blot analysis procedures according to the manufacturer's protocol. MES running buffer was used. Following electrophoresis, proteins were transferred to nitrocellulose membrane ( $30 \mathrm{~V}, 90 \mathrm{~min}$ ) followed by incubation in blocking solution ( $5 \% \mathrm{BSA}$ in $1 \mathrm{TBS}-\mathrm{T}(0.1 \%$ tween)) for one hour at room temperature. LC3B (L7543, Sigma Aldrich) primary antibody was used in a ratio of 1:2000 in 5\% milk-TBS-T, $2 \mathrm{~h}$ at room temperature. Secondary antibody, anti-rabbit (Sigma, A6154) was applied in $1: 5000$ ratio in $5 \%$ BSA-TBS-T $(0.1 \%)$ for one hour at room temperature. Actin (Sigma, A5441) primary antibody for equal loading analysis was used in 1:5000 dilution in 5\% milk-powder in TBST $(0.1 \%)$ for $1 \mathrm{~h}$ at room temperature. For visualization of the results, chemiluminescence was performed with $\mathrm{ECL}+$ kit according to the manufacturer's protocol. The chemiluminescence light was captured on X-ray film. Image software was used for quantification of band intensity. Quantification results were obtained by normalizing to actin equal loading bands and DMSO controls.

\subsubsection{Fluorescence-activated cell sorting analysis (FACS)}

Human hepatocellular carcinoma cells (Huh7) were seeded into $100-\mathrm{mm}$ culture dishes (150,000-300,000 cells/dish). After $24 \mathrm{~h}$ incubation, cells were treated with $\mathrm{IC}_{50}$ concentrations of the selected compounds for $48 \mathrm{~h}$. Then cells were trypsinized and collected as cell pellets. Samples were fixed in ice-cold $70 \%$ ethanol and stored at $-20^{\circ} \mathrm{C}$. Before the analysis, the samples were stained with MUSE Cell cycle Reagent (contains propidium iodide solution) according to the manufacturer's protocol. Cell cycle analysis was conducted with MUSE Cell Cycle Analyzer.

\section{Acknowledgment}

This work was supported by Gazi University (BAP 02/2011-44) and partly supported by Turkish Academy of Sciences (TÜBA).

\section{Appendix A. Supplementary data}

Supplementary data related to this article can be found at http:// dx.doi.org/10.1016/j.ejmech.2014.09.056.

\section{References}

[1] F.K. Keter, J. Darkwa, Perspective: the potential of pyrazole-based compounds in medicine, Biometals 25 (2012) 9-21.

[2] H. Kumar, D. Saini, S. Jain, N. Jain, Pyrazole scaffold: a remarkable tool in the development of anticancer agents, Eur. J. Med. Chem. 70 (2013) $248-258$

[3] B. Caliskan, A. Yilmaz, I. Evren, S. Menevse, O. Uludag, E. Banoglu, Synthesis and evaluation of analgesic, anti-inflammatory, and anticancer activities of new pyrazole-3(5)-carboxylic acid derivatives, Med. Chem. Res. 22 (2013) $782-793$.

[4] X.L. Ding, H.Y. Zhang, L. Qi, B.X. Zhao, S. Lian, H.S. Lv, J.Y. Miao, Synthesis of novel pyrazole carboxamide derivatives and discovery of modulators for apoptosis or autophagy in A549 lung cancer cells, Bioorg. Med. Chem. Lett. 19 (2009) 5325-5328.

[5] A.M. Farag, K.A. Ali, T.M. El-Debss, A.S. Mayhoub, A.G. Amr, N.A. Abdel-Hafez M.M. Abdulla, Design, synthesis and structure-activity relationship study of novel pyrazole-based heterocycles as potential antitumor agents, Eur. J. Med. Chem. 45 (2010) 5887-5898.

[6] S. Lian, H. Su, B.X. Zhao, W.Y. Liu, L.W. Zheng, J.Y. Miao, Synthesis and discovery of pyrazole-5-carbohydrazide $\mathrm{N}$-glycosides as inducer of autophagy in A549 lung cancer cells, Bioorg. Med. Chem. 17 (2009) 7085-7092.

[7] G.M. Nitulescu, C. Draghici, A.V. Missir, Synthesis of new pyrazole derivatives and their anticancer evaluation, Eur. J. Med. Chem. 45 (2010) 4914-4919.

[8] Y. Xia, Z.W. Dong, B.X. Zhao, X. Ge, N. Meng, D.S. Shin, J.Y. Miao, Synthesis and structure-activity relationships of novel 1-arylmethyl-3-aryl-1H-pyrazole-5carbohydrazide derivatives as potential agents against A549 lung cancer cells, Bioorg. Med. Chem. 15 (2007) 6893-6899.

[9] Y. Xia, C.D. Fan, B.X. Zhao, J. Zhao, D.S. Shin, J.Y. Miao, Synthesis and structure-activity relationships of novel 1-arylmethyl-3-aryl-1H-pyrazole-5carbohydrazide hydrazone derivatives as potential agents against A549 lung cancer cells, Eur. J. Med. Chem. 43 (2008) 2347-2353.

[10] L.W. Zheng, Y. Li, D. Ge, B.X. Zhao, Y.R. Liu, H.S. Lv, J. Ding, J.Y. Miao, Synthesis of novel oxime-containing pyrazole derivatives and discovery of regulators for apoptosis and autophagy in A549 lung cancer cells, Bioorg. Med. Chem. Lett. 20 (2010) 4766-4770.

[11] L.W. Zheng, L.L. Wu, B.X. Zhao, W.L. Dong, J.Y. Miao, Synthesis of novel substituted pyrazole-5-carbohydrazide hydrazone derivatives and discovery of a potent apoptosis inducer in A549 lung cancer cells, Bioorg. Med. Chem. 17 (2009) 1957-1962.

12] C.H. Jin, M. Krishnaiah, D. Sreenu, K.S. Rao, V.B. Subrahmanyam, C.Y. Park, J.Y. Son, Y.Y. Sheen, D.K. Kim, Synthesis and biological evaluation of 1substituted-3(5)-(6-methylpyridin-2-yl)-4-(quinolin-6-yl)pyrazoles as transforming growth factor-beta type 1 receptor kinase inhibitors, Bioorg. Med. Chem. 19 (2011) 2633-2640.

[13] C.H. Jin, M. Krishnaiah, D. Sreenu, V.B. Subrahmanyam, K.S. Rao, A.V. Mohan, C.Y. Park, J.Y. Son, Y.Y. Sheen, D.K. Kim, Synthesis and biological evaluation of 1-substituted-3-(6-methylpyridin-2-yl)-4-([1,2,4]triazolo[1,5-a]pyridin-6-yl) pyra zoles as transforming growth factor-beta type 1 receptor kinase inhibitors, Bioorg. Med. Chem. Lett. 21 (2011) 6049-6053.

[14] C.H. Jin, D. Sreenu, M. Krishnaiah, V.B. Subrahmanyam, K.S. Rao A.V. Nagendra Mohan, C.Y. Park, J.Y. Son, D.H. Son, H.J. Park, Y.Y. Sheen, D.K. Kim, Synthesis and biological evaluation of 1-substituted-3(5)-(6methylpyridin-2-yl)-4-(quinoxalin-6-yl)pyrazoles as transforming growth factor-beta type 1 receptor kinase inhibitors, Eur. J. Med. Chem. 46 (2011) 3917-3925.

[15] D.K. Kim, Y.I. Lee, Y.W. Lee, P.M. Dewang, Y.Y. Sheen, Y.W. Kim, H.J. Park J. Yoo, H.S. Lee, Y.K. Kim, Synthesis and biological evaluation of 4(5)-(6 methylpyridin-2-yl)imidazoles and -pyrazoles as transforming growth factor-beta type 1 receptor kinase inhibitors, Bioorg. Med. Chem. 18 (2010) 4459-4467

[16] F. Wei, B.X. Zhao, B. Huang, L. Zhang, C.H. Sun, W.L. Dong, D.S. Shin, J.Y. Miao, Design, synthesis, and preliminary biological evaluation of novel ethyl 1- $(2$ ' hydroxy-3'-aroxypropyl)-3-aryl-1H-pyrazole-5-carboxylate, Bioorg. Med. Chem. Lett. 16 (2006) 6342-6347.

[17] C. Maurin, F. Bailly, P. Cotelle, Improved preparation and structural investigation of 4-aryl-4-oxo-2-hydroxy-2-butenoic acids and methyl esters, Tetrahedron 60 (2004) 6479-6486.

[18] S. Levent, B. Caliskan, M. Ciftci, Y. Ozkan, I. Yenicesu, H. Unver, E. Banoglu, Pyrazole derivatives as inhibitors of arachidonic acid-induced platelet aggregation, Eur. J. Med. Chem. 64 (2013) 42-53.

19] R.H. Shoemaker, The NCI60 human tumour cell line anticancer drug screen, Nat. Rev. Cancer 6 (2006) 813-823.

[20] I.M. El-Deeb, S.H. Lee, Design and synthesis of new potent anticancer pyrazoles with high FLT3 kinase inhibitory selectivity, Bioorg. Med. Chem. 18 (2010) 3961-3973.

[21] M.I. El-Gamal, H.S. Choi, K.H. Yoo, D. Baek, C.H. Oh, Antiproliferative diarylpyrazole derivatives as dual inhibitors of the ERK pathway and COX-2, Chem. Biol. Drug Des. 82 (2013) 336-347.

[22] M.A. Dickson, G.K. Schwartz, Development of cell-cycle inhibitors for cancer therapy, Curr. Oncol. 16 (2009) 36-43.

23] G.K. Schwartz, M.A. Shah, Targeting the cell cycle: a new approach to cancer therapy, J. Clin. Oncol. 23 (2005) 9408-9421. 
[24] R. Scherz-Shouval, H. Weidberg, C. Gonen, S. Wilder, Z. Elazar, M. Oren, p53-dependent regulation of autophagy protein LC3 supports cance cell survival under prolonged starvation, PNAS 107 (2010) $18511-18516$

[25] I. Tanida, T. Ueno, E. Kominami, LC3 and autophagy, Methods Mol. Biol. 445 (2008) 77-88.
[26] L.K. Gupta, U. Bansal, S. Chandra, Spectroscopic and physicochemical studies on nickel(II) complexes of isatin-3,2'-quinolyl-hydrazones and their adducts, Spectrochim. Acta A 66 (2007) 972-975.

[27] P.E. Oefinger, D.L. Bronson, G.R. Dreesman, Induction of hepatitis B surface antigen in human hepatoma-derived cell lines, J. Gen. Virol. 53 (1981) 105-113. 